\title{
Enhanced Pharmaceutically Active Compounds Productivity from Streptomyces SUK 25: Optimization, Characterization, Mechanism and Techno-Economic Analysis
}

\author{
Muhanna Mohammed Al-Shaibani ${ }^{1,2}$, Radin Maya Saphira Radin Mohamed 1,*(D), Noraziah Mohamad Zin ${ }^{2, *}$, \\ Adel Al-Gheethi ${ }^{1, *}$, Mohammed Al-Sahari ${ }^{1}$ and Hesham Ali El Enshasy ${ }^{3,4}$ (i) \\ 1 Micro-Pollutant Research Centre (MPRC), Faculty of Civil Engineering \& Built Environment, \\ Universiti Tun Hussein Onn Malaysia, Parit Raja, 86400 Batu Pahat, Malaysia; \\ muhanan@uthm.edu.my (M.M.A.-S.); mohammedalsahari@gmail.com (M.A.-S.) \\ 2 Center for Diagnostic, Therapeutic and Investigative Studies, Faculty of Health Sciences, \\ Universiti Kebangsaan Malaysia, Jalan Raja Muda Abdul Aziz, 50300 Kuala Lumpur, Malaysia \\ 3 Institute of Bioproducts Development (IBD), Universiti Teknologi Malaysia (UTM), 81310 Skudai, Malaysia; \\ henshasy@ibd.utm.my \\ 4 City of Scientific Research and Technology Applications (SRTA), New Burg Al Arab, 21934 Alexandria, Egypt \\ * Correspondence: maya@uthm.edu.my (R.M.S.R.M.); noraziah.zin@ukm.edu.my (N.M.Z.); \\ adel@uthm.edu.my (A.A.-G.); Tel.: +607-4564236 (R.M.S.R.M.); +603-92897373 (N.M.Z.); \\ +607-4564346 (A.A.-G.); Fax: +607-4536588(R.M.S.R.M.); +601-93924639 (N.M.Z.); +607-4536588 (A.A.-G.)
}

Citation: Al-Shaibani, M.M.; Radin Mohamed, R.M.S.; Zin, N.M.; Al-Gheethi, A.; Al-Sahari, M.; El Enshasy, H.A. Enhanced Pharmaceutically Active Compounds Productivity from Streptomyces SUK 25: Optimization, Characterization, Mechanism and Techno-Economic Analysis. Molecules 2021, 26, 2510. https://doi.org/10.3390/ molecules 26092510

Academic Editors: Simona Fabroni, Krystian Marszałek and Aldo Todaro

Received: 13 March 2021

Accepted: 20 April 2021

Published: 25 April 2021

Publisher's Note: MDPI stays neutral with regard to jurisdictional claims in published maps and institutional affiliations.

Copyright: (c) 2021 by the authors Licensee MDPI, Basel, Switzerland. This article is an open access article distributed under the terms and conditions of the Creative Commons Attribution (CC BY) license (https:// creativecommons.org/licenses/by/ $4.0 /)$.

\begin{abstract}
The present research aimed to enhance the pharmaceutically active compounds' (PhACs') productivity from Streptomyces SUK 25 in submerged fermentation using response surface methodology (RSM) as a tool for optimization. Besides, the characteristics and mechanism of PhACs against methicillin-resistant Staphylococcus aureus were determined. Further, the techno-economic analysis of PhACs production was estimated. The independent factors include the following: incubation time, $\mathrm{pH}$, temperature, shaker rotation speed, the concentration of glucose, mannitol, and asparagine, although the responses were the dry weight of crude extracts, minimum inhibitory concentration, and inhibition zone and were determined by RSM. The PhACs were characterized using GC-MS and FTIR, while the mechanism of action was determined using gene ontology extracted from DNA microarray data. The results revealed that the best operating parameters for the dry mass crude extracts production were $8.20 \mathrm{mg} / \mathrm{L}$, the minimum inhibitory concentrations (MIC) value was $8.00 \mu \mathrm{g} / \mathrm{mL}$, and an inhibition zone of $17.60 \mathrm{~mm}$ was determined after 12 days, $\mathrm{pH}$ 7, temperature $28^{\circ} \mathrm{C}$, shaker rotation speed $120 \mathrm{rpm}, 1 \mathrm{~g}$ glucose /L, $3 \mathrm{~g}$ mannitol/L, and $0.5 \mathrm{~g}$ asparagine/L with $\mathrm{R}^{2}$ coefficient value of 0.70 . The GC-MS and FTIR spectra confirmed the presence of $21 \mathrm{PhACs}$, and several functional groups were detected. The gene ontology revealed that 485 genes were upregulated and nine genes were downregulated. The specific and annual operation cost of the production of PhACs was U.S. Dollar (U.S.D) 48.61 per $100 \mathrm{mg}$ compared to U.S.D 164.3/100 mg of the market price, indicating that it is economically cheaper than that at the market price.
\end{abstract}

Keywords: pharmaceutical active compounds; fermentation; optimization; Streptomyces SUK 25; response surface methodology; techno-economic analysis

\section{Introduction}

Methicillin-resistant Staphylococcus aureus (MRSA) strain is a group of strains belonging to $S$. aureus that has acquired resistance to a class of beta-lactam antibiotics. This strain represents a worldwide health problem due to its capability to become resistant to the currently available antibiotics. Moreover, MRSA infections can become severe and cause sepsis and life-threatening disease [1]. Streptomyces species have been isolated from a different environment with high potential to produce more than 10,000 of the pharmaceutically active compounds (PhACs), including alkaloid, polyene macrolide, saccharide, and 
antibiotics [2]. However, the PhACs produced depend on the source of Streptomyces species. Therefore, more studies are required to explore the ability of Streptomyces sp. to produce PhACs with high antimicrobial activity against pathogenic microorganisms. Moreover, production efficiency relies on external factors including temperature, $\mathrm{pH}$, incubation time, and shaker rotation speed, and several internal factors such as the sources of nitrogen and carbon, which should be optimized.

The one-variable-at-a-time approach design is time-consuming and complex to conduct for each separated factor, since the optimization method entails the use of a single parameter for every trial $[3,4]$. For the optimum levels to be ascertained, multiple numbers of experimental trials need to be conducted. One of the investigational techniques is the response surface methodology (RSM), which represents an important tool that employs mathematical models and statistics for the optimization of parameters of fermentation processes. Besides, RSM consists of multivariable polynomial models, which are used to optimize a response based on a given set of variables. In addition, there is a wide application of the RSM approach in the optimization of microbial fermentation processes, as well as in the determination of the effect of various factors. A different approach used to increase engineered strain's expression is the application of biostatistics to optimize culture conditions, with the RSM optimization with central composite design (CCD) being the widely accepted design [5].

The gas chromatography mass spectroscopy (GC-MS) analysis involves the combination of technologies for the analysis of chemical compounds. The GC executes the separation of the compounds, whereas the MS produces the specific mass profiles of each of the detected compounds. The analysis of emissions from biogenic volatile organic compounds (VOCs) is commonly executed using GC-MS [6].

VOCs are typically small and odorous compounds manufactured as secondary metabolites produced by some microorganisms and microorganisms associated with plants and soil [7].

The chloramphenicol (CAP) and seven diketopiperazines (DKP) were isolated, purified, and identified from SUK 25 as a bacteriostatic antibiotic [3,4]. The mode of action of CAP and DKP involves the inhibition of protein synthesis, which is achieved by preventing the elongation of the protein chain through the inactivation of the activity of peptidyl transferase present in the bacterial ribosomes as reported by Zin et al. [8].

Gene ontology (GO) is a bioinformatics technique that combines intra- and interspecies representation of gene and gene product attributes. GO consists of three main aspects: the biological process, its molecular function, and the cellular function, as the technique allows operators to describe and define a gene/gene product in detail [9].

The techno-economic analysis (TEA) is an ingrained process, which is developed in performance with technology, to confirm that market-driven prices can be realized [10]. TEA is a part of the stage-gate process in product development and related research. It is a technically and economically interrelated invention and encouragement in most industries [11]. TEA is a study of a production process in an industry sector to determine roughly how effectively the economy or something within it is operating. In addition, it assesses the details of how you intend to deliver a product or service to customers and has shown the costs involved in the production of products [12,13].

The present study aimed to optimize the PhACs productivity from Streptomyces SUK 25 in submerged fermentation (SmF) using RSM. Furthermore, the characteristics and mechanism of action of the PhACs against MRSA were determined. Besides, the techno-economic analysis of PhACs production was estimated to studying the applicability of the generated compounds to be used as an alternative for the commercial antimicrobial products.

\section{Results}

\subsection{RSM-Based Optimization of PHACs Production}

The optimization of the production using SmF process was conducted with seven independent factors and three dependent variables as represented in Table S1. The maxi- 
mum crude extracts production $\left(y_{1}\right)$ was 8.20 vs. $8.58 \mathrm{mg} / \mathrm{L}$ of the actual and the predicted results, respectively. The maximum MIC $\left(y_{2}\right)$ activity obtained $10.40 \mathrm{vs} .8 .00 \mu \mathrm{g} / \mathrm{mL}$ for the predicted and actual results, respectively. For the maximum I.Z $\left(y_{3}\right)$ values, the predicted and actual results were 18.03 vs. $17.60 \mathrm{~mm}$, respectively. These findings were recorded after 12 days, at $\mathrm{pH} 7$, temperature $28^{\circ} \mathrm{C}$, speed $120 \mathrm{rpm}, 1 \mathrm{~g}$ glucose $/ \mathrm{L}, 3 \mathrm{~g}$ mannitol/L, and $0.5 \mathrm{~g}$ asparagine/L. These results specified that the explored factors represent an essential starring role in the production of crude extracts, increasing inhibition zone (I.Z), and improving the MIC activity. The productivity of the amount of crude extracts $\left(y_{1}\right)$ was associated positively and significantly $(p<0.05)$ with the incubation time (days) $x_{1}$ and $\mathrm{pH} x_{2}$ factors, while having a non-significant correlation with other factors $x_{3}-x_{7}$, as described in Table 1 and Table S2. In contrast, the incubation time $x_{1}, \mathrm{pH} x_{2}$, and temperature $x_{3}$ revealed a significant negative quadratic effect on amount of crude extract $\left(y_{1}\right)$, while the other factors $x_{4}-x_{7}$ had a non-significant quadratic effect on the amount of crude extracts. The good activity and low MIC $\left(y_{2}\right)$ was related positively and statistically significant $(p<0.05)$ with factors $x_{3}, x_{4}, x_{5}$, and $x_{7}$, while having a non-significant correlation with factors $x_{1}$ and $x_{2}$. In contrast, all responses exhibited a significant negative quadratic effect on the MIC values. The best and wide I.Z $\left(y_{3}\right)$ was related positively and statistically significant $(p<0.05)$ with factors $x_{1}$, and $x_{2}$, while having a non-significant correlation with factors temperature $x_{3}$, speed $x_{4}$, glucose $x_{5}$, mannitol $x_{6}$, and asparagine $x_{7}$. In contrast, $x_{1}, x_{2}, x_{3}$, and $x_{4}$ displayed a significant negative quadratic effect on the size of the I.Z, while there was a non-significant correlation for $x_{5}, x_{6}$, and $x_{7}$ factors, as described in Table 1. The ANOVA analysis for the quadratic model, as clarified in Table 2 and Table S2, indicated that independent factors $\left(x_{1}-x_{7}\right)$ contributed significantly $(p<0.05)$ with $R^{2}=0.70$ of the coefficient for amount of crude extracts $y_{1}, R^{2}=0.63$ for MIC $y_{2}$, and $\mathrm{R}^{2}=0.75$ for the I.Z $y_{3}$. These findings verify the appropriateness of the model.

Table 1. Analysis of the variance (ANOVA) of the response surface quadratic model for pharmaceutically active compounds production from Streptomyces SUK 25.

\begin{tabular}{|c|c|c|c|c|c|c|c|c|c|c|c|c|c|}
\hline \multirow{2}{*}{ Source } & \multirow{2}{*}{ DF } & \multicolumn{3}{|c|}{ Sum of Squares } & \multicolumn{3}{|c|}{ Mean Square } & \multicolumn{3}{|c|}{ F Value } & \multicolumn{3}{|c|}{$p$-Value } \\
\hline & & $y_{1}$ & $y_{2}$ & $y_{3}$ & $y_{1}$ & $y_{2}$ & $y_{3}$ & $y_{1}$ & $y_{2}$ & $y_{3}$ & $y_{1}$ & $y_{2}$ & $y_{3}$ \\
\hline Model & 14 & 6.98 & 636.49 & 23.16 & 6.98 & 636.49 & 23.16 & 3.80 & 2.70 & 4.83 & $\begin{array}{c}0.0026 \\
\text { Significant }\end{array}$ & $\begin{array}{c}0.0180 \\
\text { Significant }\end{array}$ & $\begin{array}{c}0.0005 \\
\text { Significant }\end{array}$ \\
\hline $\begin{array}{l}\text { Residual } \\
\text { error }\end{array}$ & 22 & 1.84 & 235.51 & 4.80 & 1.84 & 235.51 & 4.80 & & & & & & \\
\hline Lack-of-fit & 16 & 2.40 & 211.33 & 5.82 & 2.40 & 211.33 & 5.82 & 7.20 & 0.7044 & 2.79 & $\begin{array}{c}0.0112 \\
\text { Significant }\end{array}$ & $\begin{array}{c}0.7327 \\
\text { Not } \\
\text { significant }\end{array}$ & $\begin{array}{c}0.1053 \\
\text { Not } \\
\text { significant }\end{array}$ \\
\hline Pure error & 6 & 0.3333 & 300.00 & 2.08 & 0.3333 & 300.00 & 2.08 & & & & & & \\
\hline Total & 36 & & & & & & & & & & & & \\
\hline
\end{tabular}

The standard error of regression was used to detect the fitting of the experimental and predicted results. The value of the standard error of regression recorded in this study ranged from 0.49 to 2.17 for amount of crude extracts $\left(y_{1}\right)$ and from 0.79 to 3.52 for I.Z $y_{3}$, which indicate the accuracy of the experimental results. In contrast, the standard error of $y_{2}$ was between 8.22 and 24.63; this error was high and might be related to the nature of the response and measurement methods where the MIC represented good response when it was in low value. 
Table 2. Antimicrobial compounds identified in the ethyl acetate extract by GC-MS from fraction no. 2.

\begin{tabular}{|c|c|c|c|c|c|c|c|c|}
\hline Peak no & $\begin{array}{c}\text { R. } \\
\text { Time }\end{array}$ & $\begin{array}{l}\text { Name of the } \\
\text { Compound }\end{array}$ & $\begin{array}{l}\text { Molecular } \\
\text { Formula }\end{array}$ & $\begin{array}{l}\text { Molecular } \\
\text { Weight } \\
\text { (g/mol) }\end{array}$ & Area \% & Quality (\%) & Activity & References \\
\hline 1 & 5.799 & n-dodecane & $\mathrm{C}_{12} \mathrm{H}_{26}$ & 170 & 0.66 & 76 & $\begin{array}{l}\text { Antioxidants, } \\
\text { antimicro- } \\
\text { bial }\end{array}$ & {$[14,15]$} \\
\hline 2 & 9.908 & Eicosane & $\mathrm{C}_{20} \mathrm{H}_{42}$ & 283 & 1.38 & 74 & $\begin{array}{l}\text { Antibacterial, } \\
\text { antifungal }\end{array}$ & [16] \\
\hline 3 & 10.200 & $\begin{array}{l}\text { Phenol, 2,5-bis } \\
\text { (1,1-dimethyl } \\
\text { ethyl) }\end{array}$ & $\mathrm{C}_{14} \mathrm{H}_{22} \mathrm{O}$ & 206 & 2.24 & 87 & Antimicrobial & {$[17,18]$} \\
\hline 4 & 21.893 & Cetene & $\mathrm{C}_{16} \mathrm{H}_{32}$ & 29 & 0.82 & 75 & Antioxidants & [19] \\
\hline 5 & 23.482 & Diethylphthalate & $\mathrm{C}_{12} \mathrm{H}_{14} \mathrm{O} 4$ & 222 & 3.92 & 88 & Antimicrobial & [16] \\
\hline 6 & 25.037 & $\begin{array}{c}2- \\
\text { methyloctacosane }\end{array}$ & $\mathrm{C}_{29} \mathrm{H}_{60}$ & 409 & 0.81 & 94 & Antifungal & [20] \\
\hline 7 & 25.330 & 1-octadecane & $\mathrm{C}_{18} \mathrm{H}_{36}$ & 252 & 0.86 & 75 & Antifungal & [21] \\
\hline 8 & 28.775 & $\begin{array}{l}\text { Phthalic acid, } \\
\text { isobutyl nonyl } \\
\text { ester }\end{array}$ & $\mathrm{C}_{21} \mathrm{H}_{32} \mathrm{O}_{4}$ & 348 & 1.11 & 79 & $\begin{array}{l}\text { Antimicrobial, } \\
\text { antioxidants }\end{array}$ & [22] \\
\hline 9 & 29.896 & Heneicosane & $\mathrm{C}_{21} \mathrm{H}_{44}$ & 297 & 1.86 & 74 & Antibacterial & [23] \\
\hline 10 & 31.735 & $\begin{array}{l}\text { n-hexa-decanoic } \\
\text { acid }\end{array}$ & $\mathrm{C}_{16} \mathrm{H}_{32} \mathrm{O}_{2}$ & 256 & 1.02 & 73 & $\begin{array}{l}\text { Cosmetics, } \\
\text { antioxidants }\end{array}$ & {$[24,25]$} \\
\hline
\end{tabular}

The equation for the linear and quadratic influence of the independent factors on the dependent variables were presented in Equations (1)-(3).

$$
\begin{aligned}
& y_{1}=1.86+2.49 x_{1 *}+3.07 x_{2 *}+0.22 x_{3}-1.13 x_{4}-0.39-0.099 x_{6}-0.27 x_{7}-4.42 x_{1 *}^{2}-2.19 x_{3}^{2}+0.22 x_{4}^{2} \\
& +1.36 x_{5}^{2}+1.70 x_{6}^{2}+1.31 x_{7}^{2} \\
& y_{2}=10.03+11.90 x_{1}+1.79 x_{2}-17.01 x_{3 *}-25.60 x_{4 *}--26.50 x_{5 *}+13.41 x_{6 *}+8.03 x_{7}-8.48 x_{1}^{2}-0.015 x_{2}^{2} \\
& -33.44 x_{3 *}^{2}-24.00 x_{4 *}^{2}-26.15 x_{5 *}^{2}-10.75 x_{6}^{2} 19.03 x_{7}^{2} \\
& y_{3}=9.07+6.48 x_{1 *}+4.18 x_{2 *}-0.75 x_{3}-1.93 x_{4}-1.45 x_{5}+0.63 x_{6}-0.25 x_{7}-7.23 x_{1 *}^{2}-1.68 x_{2}^{2}-3.37 x_{3}^{2} \\
& -1.61 x_{4}^{2}+1.33 x_{5}^{2}+2.30 x_{6}^{2}+1.59 x_{7}^{2}
\end{aligned}
$$

where ${ }^{*}$ represents the factors that have a significant role; $x_{1}$ (time) (day), $x_{2}(\mathrm{pH}), x_{3}$ (temperature) $\left({ }^{\circ} \mathrm{C}\right), x_{4}$ (speed) $(\mathrm{rpm}), x_{5}$ (glucose) $(\mathrm{g} / \mathrm{L}), x_{6}$ (mannitol) $(\mathrm{g} / \mathrm{L}), x_{7}$ (asparagine) (g/L), $y_{1}$ (crude extracts) $(\mathrm{mg} / \mathrm{L}), y_{2}$ (MIC) $(\mu \mathrm{g} / \mathrm{mL}), y_{3}$ (I.Z) (mm).

\subsection{Validation of the Optimal Parameters}

The best operating parameters for producing PhACs were determined after 12 days at $\mathrm{pH} 7$, temperature $28^{\circ} \mathrm{C}$, shaker rotation speed $120 \mathrm{rpm},(1 \mathrm{~g})$ glucose $/ \mathrm{L},(3 \mathrm{~g})$ mannitol $/ \mathrm{L},(0.5 \mathrm{~g})$ asparagine/ $\mathrm{L}$ with $95 \%$ of the confidence level and $0.5 \%$ of significance. The autonomous considerations correlated significantly $(p<0.05)$ just at perfect circumstances of the SmF process. This evidently shows that interaction effects occur, as one factor's influence depends mostly on another factor as represented in (Figure 1a-1). The results revealed that the internal factors glucose, mannitol, and asparagine $\left(x_{5}, x_{6}, x_{7}\right)$ have independent effects on the productivity of amount of crude extract $y_{1}$ without a significant interaction (Figure 1a-c). However, the external factors $x_{1}$ (incubation time), $x_{2}(\mathrm{pH}), x_{3}$ (temperature), $x_{4}$ (speed) exhibited a significant synergistic effect on the productivity of the amount of the crude extract as represented in (Figure 1d,g,k,l). Moreover, the external factors showed more influence on the amount of crude extract $y_{1}$ compared to the internal factors. Nonetheless, the external factors exhibited a synergistic interaction with the internal factors (Figure $1 \mathrm{e}, \mathrm{f}, \mathrm{h}-\mathrm{j})$ ). In contrast, the data analysis of the interactions of the factors revealed that the internal factors $\left(x_{5}, x_{6}, x_{7}\right)$ have a synergistic interaction to MIC activity 
as shown in (Figure S1b,e,f). The internal factors exhibited significant synergistic effects on MIC activity, as revealed in (Figure S1a,d,e), more than the external factors (Figure S1j-1)). The internal factors have no significant interaction and effects on $y_{3}$ (Figure S2i), while the external factors exhibited more efficiency in improving $y_{3}$ (Figure S2a-c,g,h).

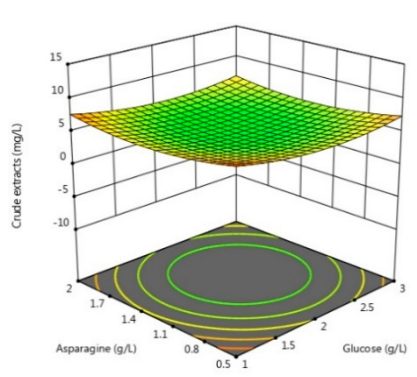

(a)

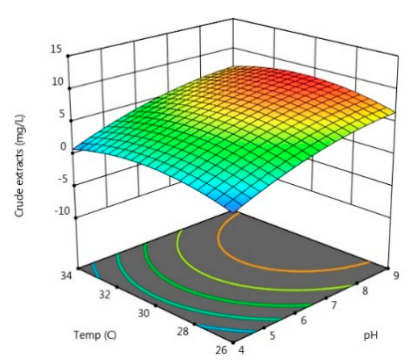

(d)

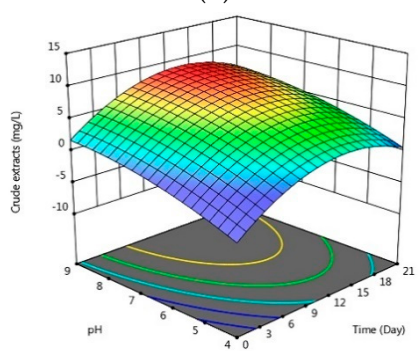

(g)

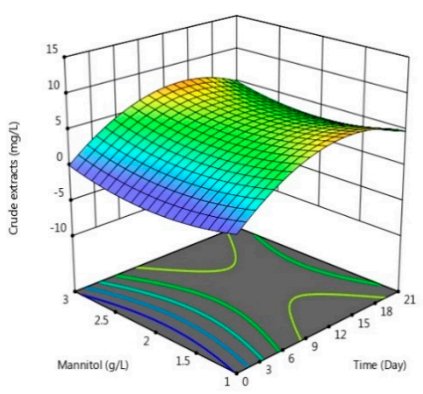

(j)

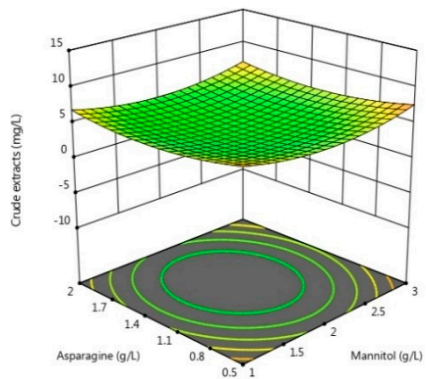

(b)

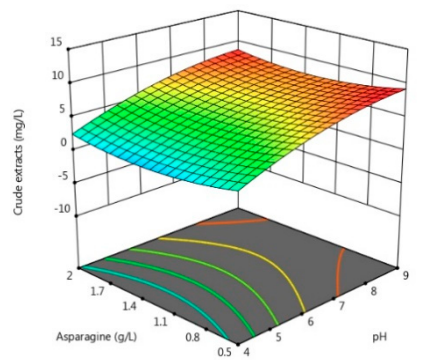

(e)

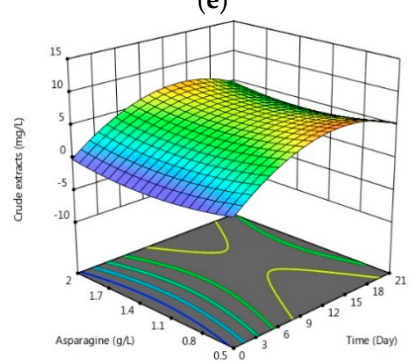

(h)

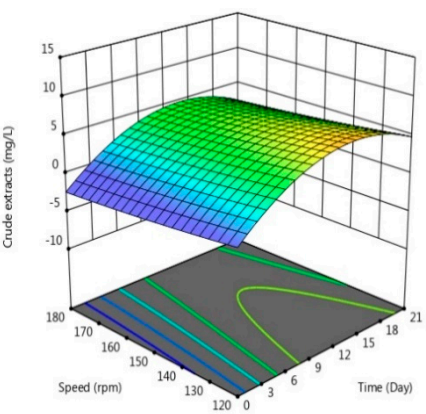

(k)

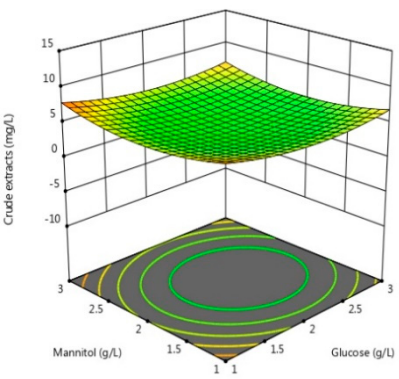

(c)

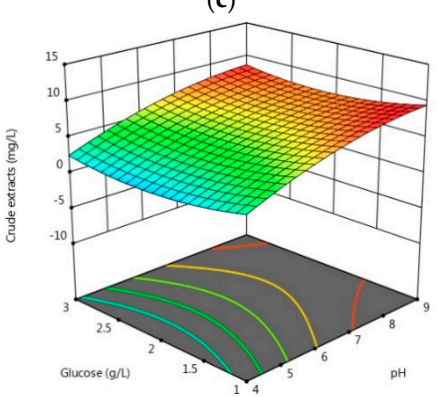

(f)

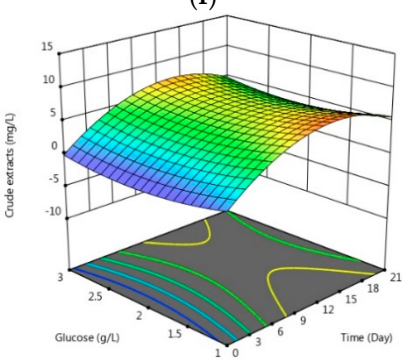

(i)

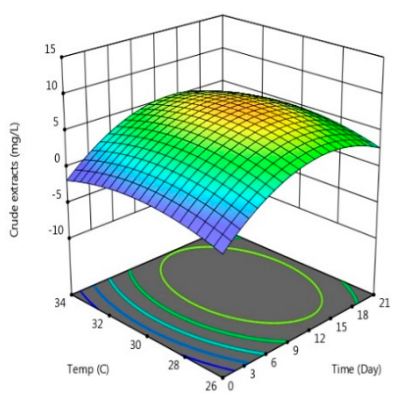

(1)

Figure 1. Three-dimensional response surface plot for interactions between $x_{1}$ (time) (day), $x_{2}(\mathrm{pH}), x_{3}$ (temperature) $\left({ }^{\circ} \mathrm{C}\right)$, $x_{4}$ (speed) (rpm), $x_{5}$ (glucose) $(\mathrm{g} / \mathrm{L}), x_{6}$ (mannitol) $(\mathrm{g} / \mathrm{L}), x_{7}$ (asparagine) $(\mathrm{g} / \mathrm{L})$, and their effects on $y_{1}$ (crude extracts) $(\mathrm{mg} / \mathrm{L})$. (a) Effects of asparagine and glucose on weight of crude extract; (b) Effects of asparagine and mannitol on weight of crude extract; (c) Effects of mannitol and glucose on weight of crude extract; (d) Effects of temperature and $\mathrm{pH}$ on the weight of crude extract; (e) Effects of asparagine and $\mathrm{pH}$ on weight of crude extract; (f) Effects of glucose and $\mathrm{pH}$ on the weight of crude extract; (g) Effects of $\mathrm{pH}$ and time on the weight of crude extract; (h) Effects of asparagine and time on the weight of crude extract; (i) Effects of glucose and time on the weight of crude extract; (j) Effects of mannitol and time on the weight of crude extract; (k) Effects of speed and time on the weight of crude extract; (1) Effects of temperature and time on the weight of crude extract. 
The Plackett-Burman design was used to screen and select the components of the compelling media. The resulting data indicated that the internal factors such as glucose, asparagine, and mannitol had positive impacts in contrast to the other components in the medium. Additionally, other external factors including the $\mathrm{pH}$, duration of incubation, and shaker rotation speed had positive effects. In this study, the obtained $\mathrm{R}^{2}$ value $(0.70)$ indicated that the model explained $70 \%$ of the overall variation. When $\mathrm{R}^{2}$ is closer to 1 , the strength of the model is improved and makes a better prediction of the response. Following the RSM-based optimization, the increment in the antibacterial activity of PHACs was affirmed after comparing the results to the one-at-a-time strategy design medium. With deference to the weight of the crude extract, the antibacterial activities against MRSA ATCC 43300 and MIC were improved from 5.6 to $8.2 \mathrm{~g} / \mathrm{L}(42.9 \%)$ and from 16 to 8 and $4 \mu \mathrm{g} / \mathrm{mL}$ $(50 \%)$, respectively.

The increment in the zone of inhibition was from $11.4 \pm 1.5$ to $17.2 \pm 1.5 \mathrm{~mm}$. Based on the $(50.9 \%)$ increase in the modified media, the finding suggests that the antibacterial metabolite production by SUK 25 was affected by the quantity of the media components. Therefore, the present experimental design enhanced the optimization of significant media components with a high level of accuracy. Accordingly, this is the first study to report a $50.9 \%$ increase in antibacterial activity against MRSA ATCC 43300 from an endophytic Streptomyces SUK 25.

\subsection{Column Chromatography and Thin-Layer Chromatography}

The present study showed that 13 fractions were collected from the crude ethyl acetate extract of SUK 25 according to the gradient elution solvent by using column chromatography. The fractions with similar $\mathrm{R}_{f}$ in TLC were evenly mixed. Only seven pure compounds were separated from fraction number 2 and fraction number 7 . These compounds were purified, identified, and characterized by using HPLC, LS-MS, and NMR as reported by our previous studies carried by [6,7].

\subsection{Determination of Antibacterial Activity by Using MIC and Disc Diffusion Method}

The mean MICs of the triplicate samples for fraction number 2 and fraction number 7 at the best fermentation conditions against MRSA ATCC 43300 were 4 and $8 \mu$, respectively. In addition, the mean diameters of the triplicate samples for I.Z against the same bacteria were $17.2 \pm 1.2 \mathrm{~mm}$ and $17 \pm 1.3 \mathrm{~mm}$.

\subsection{Fourier Transform Infrared Spectroscopy}

The presence of different compounds from various functional groups was detected. In this study, the FTIR spectroscopy demonstrated its reliability and sensitivity for the detection of bimolecular composition. The dominant bands in the case of crude extract were observed at 3348, 3319, 2945, 2833, 1558, 1449, $1394 \mathrm{~cm}^{-1}$. The bands at 1121, 1092, and $972 \mathrm{~cm}^{-1}$ are due to the presence of C $-\mathrm{O}$ stretch (primary alcohol) and $=\mathrm{C}-\mathrm{H}$ bend alkenes, $\mathrm{O}-\mathrm{H}$ bending as carboxylic acids. The absorption spectra of the column compounds' extract samples are depicted in (Figure 2) and (Table S3). 


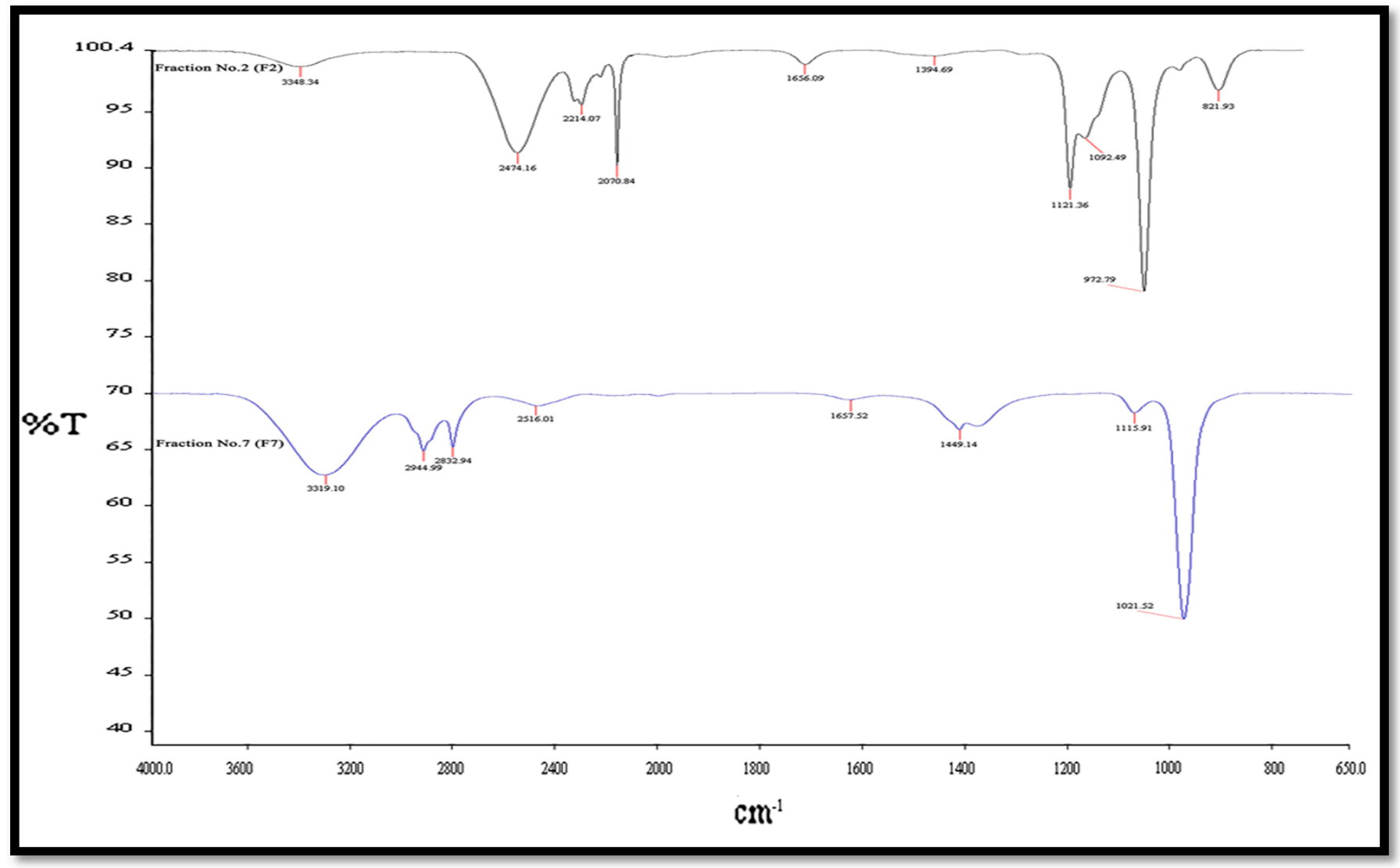

Figure 2. The Fourier transform infrared spectroscopy for fraction number 2 and 7.

\subsection{GC-MS Analysis of Volatile Components}

The GC-MS analysis of the volatile components of Streptomyces SUK 25 using the NCBI PubChem bioassay database. The peaks were prudently identified based by comparing the features of the mass spectral and NIST database. The analysis revealed that among the 38 peaks, as demonstrated in (Figure 3), the 21 compounds that demonstrated the presence of bioactive constituents have been previously documented for their antioxidant, antimicrobial, antifungal, and anti-adherence activities. Other functions include neurotropic action and presence of anti-inflammatory activates such as n-dodecane (1), eicosane (2), phenol, 2,5-bis (1,1-dimethyl ethyl) (3), cetene (4), diethylphthalate (5), 2-methyloctacosane (6), 1octadecane (7), phthalic acid, isobutyl nonyl ester (8), heneicosane (9), and n-hexa decanoic acid (10) were isolated from fraction no. 2 as represented in Table 2. From fraction no. 7, eleven compounds were identified as di-butyl phthalate (11), 1-nonadecene, thieno [3,2-e] benzofuran(12), (1-decene) (13), di-isooctyl phthalate (14), bis (2-ethyl hexyl) phthalate (15), dodecane (16), eicosane (17), heneicosane (18), 1,2-benzenedi carboxylic acid (19), lauric acid (20), and dodecanoic acid (21). According to the previous literature, these compounds were isolated from other aforementioned studies.

Tables 2 and 3 represents the name of the compound, molecular formula, molecular weight, area, quality, and activity. In addition, Figure 4 illustrates the compounds and their chemical structures. 


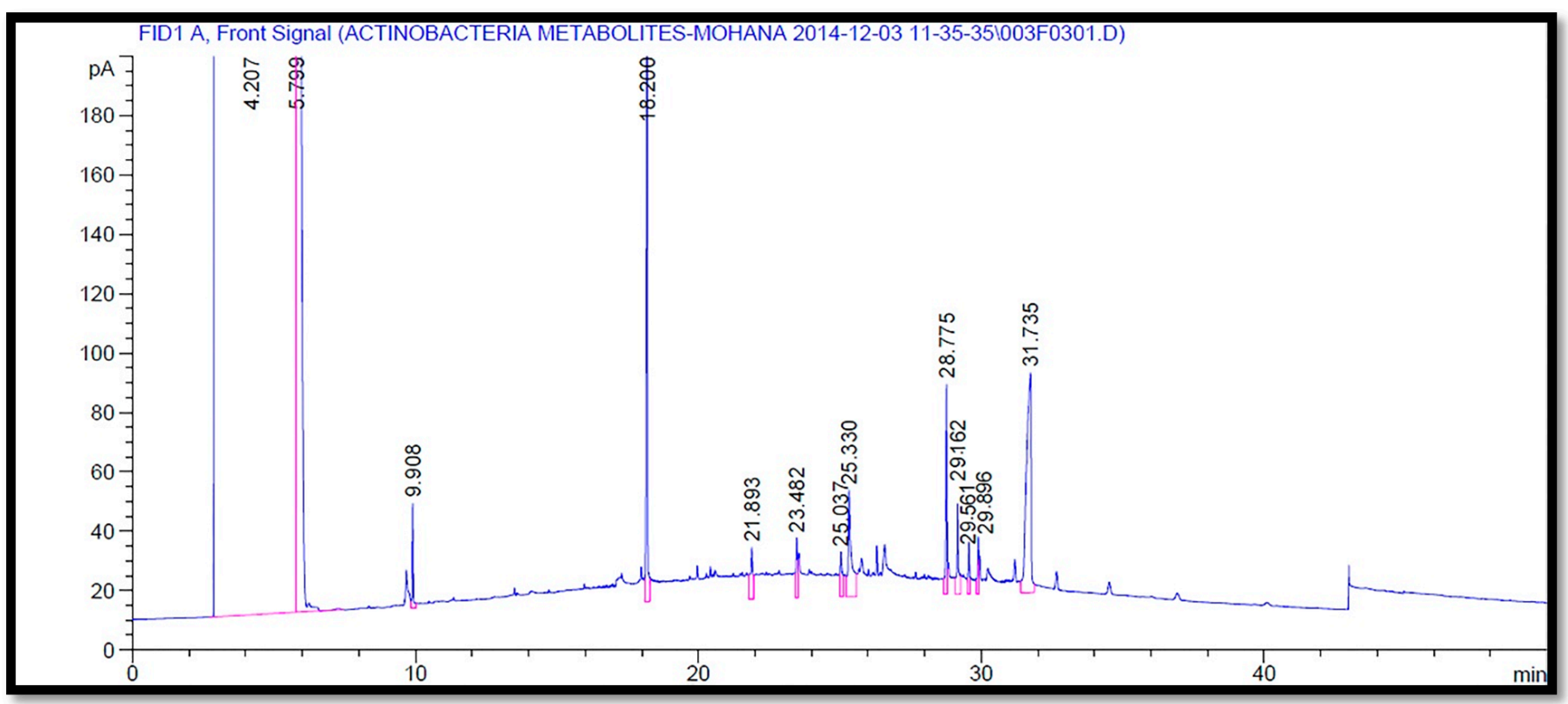

Figure 3. The GC-MS chromatograms analysis of volatile organic compounds of the ethanolic crude extract in fraction number 2 at different retention times.

Table 3. Antimicrobial compounds identified in the ethyl acetate extract by GC-MS from fraction no. 7.

\begin{tabular}{|c|c|c|c|c|c|c|c|c|}
\hline Peak no & R. Time & $\begin{array}{l}\text { Name of the } \\
\text { Compound }\end{array}$ & $\begin{array}{l}\text { Molecular } \\
\text { Formula }\end{array}$ & $\begin{array}{l}\text { Molecular } \\
\text { Weight } \\
\text { (g/mol) }\end{array}$ & $\underset{\%}{\text { Area }}$ & Quality (\%) & Activity & References \\
\hline 1 & 17.671 & $\begin{array}{l}\text { Di-butyl } \\
\text { phthalate }\end{array}$ & $\mathrm{C}_{16} \mathrm{H}_{22} \mathrm{O}_{4}$ & 278 & 2.64 & 86 & Antifungal & [26] \\
\hline 2 & 12.301 & 1-nonadecene & $\mathrm{C}_{19} \mathrm{H}_{38}$ & 267 & 0.85 & 79 & $\begin{array}{l}\text { Antioxidants, } \\
\text { antimicro- } \\
\text { bial }\end{array}$ & [27] \\
\hline 3 & 12.734 & $\begin{array}{l}\text { Thieno[3,2-e] } \\
\text { benzofuran }\end{array}$ & $\mathrm{C}_{10} \mathrm{H}_{6} \mathrm{OS}$ & 174 & 1.20 & 92 & Antibacterial & [28] \\
\hline 4 & 13.279 & (1-decene) & $\mathrm{C}_{10} \mathrm{H}_{20}$ & 140 & 0.46 & 85 & Antifungal & [29] \\
\hline 5 & 13.509 & $\begin{array}{l}\text { Diisooctyl } \\
\text { phthalate }\end{array}$ & $\mathrm{C}_{24} \mathrm{H}_{38} \mathrm{O}_{4}$ & 391 & 1.11 & 98 & $\begin{array}{c}\text { Anticancer, } \\
\text { antibacterial }\end{array}$ & [30] \\
\hline 6 & 13.590 & $\begin{array}{c}\text { Bis (2-ethyl } \\
\text { hexyl) phthalate }\end{array}$ & $\mathrm{C}_{24} \mathrm{H}_{38} \mathrm{O}_{4}$ & 391.56 & 79.06 & 94 & Antimicrobial & [31] \\
\hline 7 & 14.084 & Dodecane & $\mathrm{C}_{12} \mathrm{H}_{26}$ & 170 & 19.41 & 69 & $\begin{array}{l}\text { neurotropic } \\
\text { action }\end{array}$ & {$[14,15]$} \\
\hline 8 & 17.762 & Eicosane & $\mathrm{C}_{20} \mathrm{H}_{42}$ & 283 & 5.31 & 71 & $\begin{array}{l}\text { Antimicrobial, } \\
\text { Antifungal }\end{array}$ & [16] \\
\hline 9 & 18.532 & Heneicosane & $\mathrm{C}_{21} \mathrm{H}_{44}$ & 296 & 3.70 & 72 & Antifungal & [23] \\
\hline 10 & 19.648 & $\begin{array}{l}\text { 1,2-benzenedi } \\
\text { carboxylic acid }\end{array}$ & $\mathrm{C}_{8} \mathrm{H}_{6} \mathrm{O}_{4}$ & 166.14 & 3.1 & 93 & $\begin{array}{l}\text { Antimicrobial } \\
\text { and anti- } \\
\text { inflammatory } \\
\text { Activities }\end{array}$ & [32] \\
\hline 11 & 25.431 & $\begin{array}{c}\text { Lauric acid, } \\
\text { dodecanoic acid }\end{array}$ & $\mathrm{C}_{12} \mathrm{H}_{24} \mathrm{O}_{2}$ & 200.32 & 2.1 & 74 & $\begin{array}{l}\text { Antimicrobial } \\
\text { and anti- } \\
\text { inflammatory } \\
\text { Activities }\end{array}$ & [33] \\
\hline
\end{tabular}




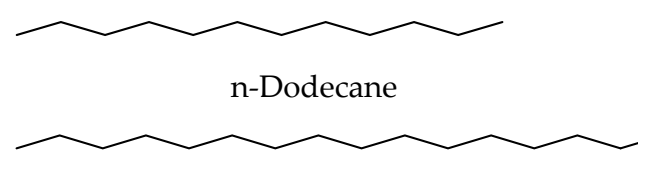

Eicosane
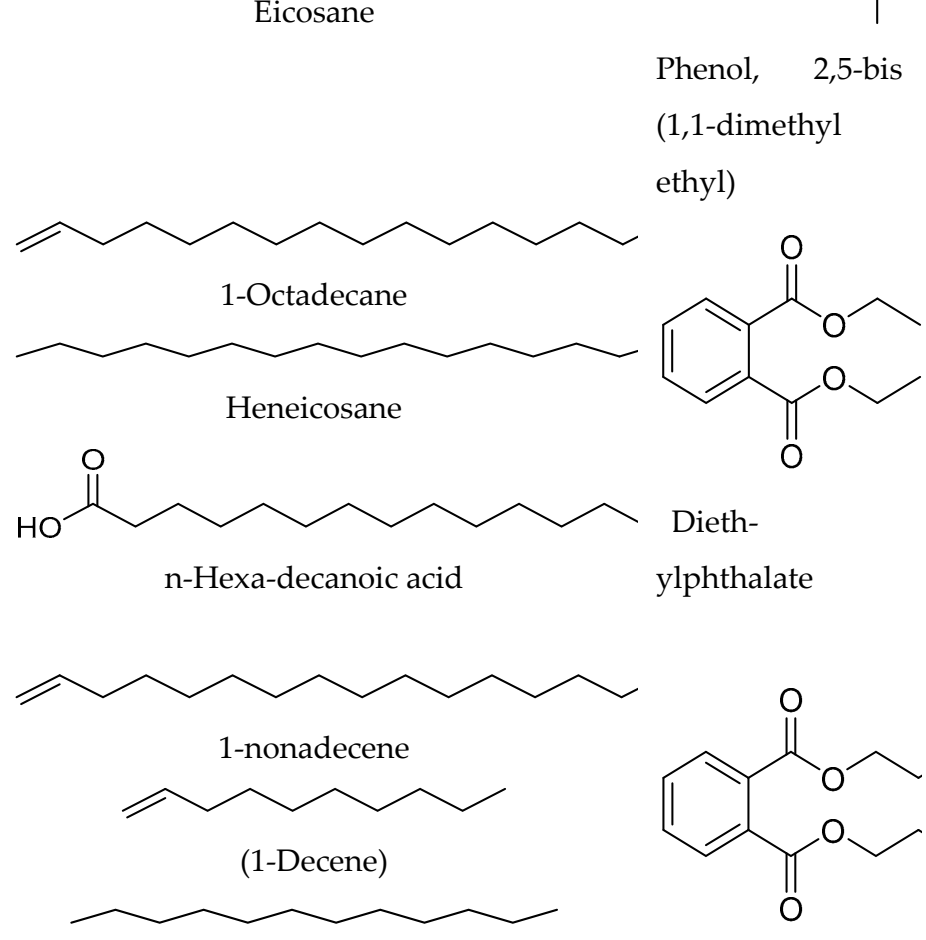

Dodecane

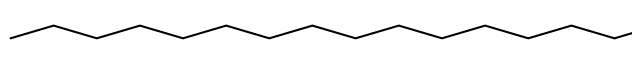

Eicosane

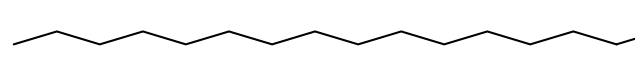

Heneicosane<smiles>CCCCCCCCCCCC(=O)O</smiles>

Lauric Acid, Dodecanoic Acid<smiles>CC(C)(C)c1ccc(C(C)(C)C)c(O)c1</smiles>

2,5-bis (1,1-dimethyl<smiles>CCOC(=O)c1ccccc1C(=O)OCC</smiles>
Di-butyl phthalate<smiles>c1cc2c(ccc3sccc32)o1</smiles>

\section{Thieno[3,2-e]} benzofuran<smiles>O=C(O)c1ccccc1C(=O)O</smiles><smiles>C=CCCCCCCCCCCCCCC</smiles><smiles>CCCCCCCCCCCCCCCCCCCC(C)C</smiles>
2-methyloctacosane<smiles>CC(C)CCCCCOC(=O)c1ccccc1C(=O)OCCCCCC(C)C</smiles>

Diisooctyl phthalate<smiles>CCCCC(CC)COC(=O)c1ccccc1C(=O)OCC(CC)CCCC</smiles>

Bis (2-ethyl hexyl) phthalate

\section{1,2-Benzenedi}

Carboxylic acid

Figure 4. The chemical structure of the antimicrobial compounds identified by GC-MS from crude extract of SUK 25.

\subsection{Gene Ontology and Pathway Analysis}

Gene ontology analyses of hits with DAVID for the DNA microarray experiments using CAP and cyclo-(L-Val-L-Pro), as a representative for DKP revealed 485 genes upregulated and nine genes that were downregulated. A total of 74 genes were considered to be upregulated in the biological function group. Most categories were under the adenosine monophosphate (AMP) salvage pathways (25 gens), translation category ( 24 genes), 
metabolic process (13 genes), followed by an oxidation-reduction process (12 genes). Besides, nine genes were downregulated in the biological function under categories of the cell cycle, cell division, and cellular amino acid metabolic process. In addition, 153 genes were considered upregulated in the cellular function. The furthermost categories were under ribonucleoprotein complex (16 genes), ribosome (25 genes), and cytoplasm (19 genes). Moreover, 258 genes upregulated in the molecular function level.

Scattered under RNA binding (28 genes), transferase activity (20 genes), and structural constituent of ribosome (19 genes), oxidoreductase activity (15 genes), and catalytic activity (14 genes). The other genes, which were not documented, were under hypothetical proteins. The mode of action of PhACs against MRSA ATCC 43300 was an inhibition of translation process, as shown in (Figure 5).

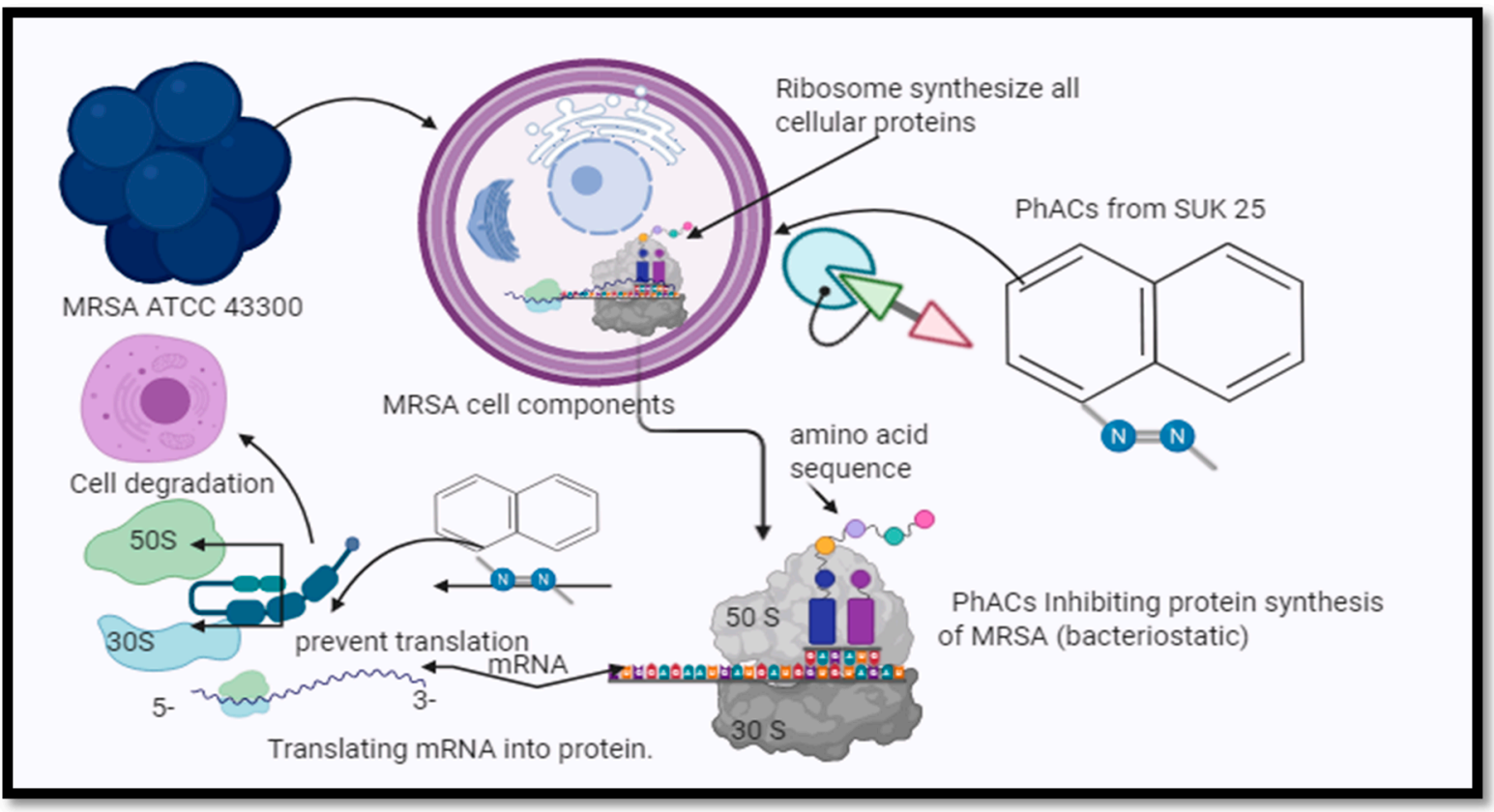

Figure 5. The mode of action of PhACs from SUK 25 against MRSA ATCC 43300. PhACs from SUK 25 stop the translation process and prevent the cell to converts genetic information carried in an mRNA molecule.

\subsection{Techno-Economic Analysis of the PhACs Productivity from SUK 25}

The annual report functioning period for production PhACs in the SmF process is $3300 \mathrm{~h}$ /year (interchangeable for 330 handling days). The complete capital expenditure (TCI) for a recommended plant together with the secure capital guesstimate (FCE) and functioning working capital cost (WCC) (Equation (4)).

$$
\mathrm{TCI}=\mathrm{FCE}+\mathrm{WCC}
$$

The FCE involves the cost of purchasing equipment, installation of the system, process piping, electronic systems, percussion and sensors, yard upgrades, buildings, and perhaps even the cost of WCC, which, as indicated by Herrera-Rodriguez et al. [34], may constitute $6.5 \%$ of the FCE. Consequently, the FCE to plan a production process with $1000 \mathrm{~m}^{3} /$ day of aptitude reaches U.S. Dollar (U.S.D) 507,000.00, as described in Table 4. 
Table 4. The fixed capital estimate (FCE) for production of PhACs by the SUK 25 using the submerged fermentation process.

\begin{tabular}{|c|c|c|c|c|}
\hline Item Code * & Quantity & Item & $\begin{array}{c}\text { Percentage of } \\
\text { FCE }\end{array}$ & Cost \\
\hline P-1/BR-101 & 1 & Cell culture bio-reactor & \multirow{10}{*}{$33.33 \%$} & $10,000.00$ \\
\hline P-1/DS-101 & 2 & Centrifuge & & $30,000.00$ \\
\hline P-1/MSX-101 & 1 & Purification system & & $17,000.00$ \\
\hline P-1/FDR-101 & 1 & Freeze drying & & 5000.00 \\
\hline P-1/RBS-101 & 1 & Inoculum preparation & & 5000.00 \\
\hline P-2/V-101 & 2 & Storage tank & & $25,000.00$ \\
\hline P-1/MF-101 & 1 & Microfiltration & & $14,000.00$ \\
\hline P-1/AB-101 & 1 & Aerobic bio-oxidation & & $30,000.00$ \\
\hline P-2/DE-101 & 1 & Dead end filtration & & $20,000.00$ \\
\hline \multirow[t]{10}{*}{ P-1/DB-101 } & 1 & Biomass storage tank & & $13,000.00$ \\
\hline & & \multicolumn{2}{|c|}{ Total equipment purchase cost } & $169,000.00$ \\
\hline & & Equipment installation & $9.86 \%$ & $50,000.00$ \\
\hline & & Process piping & $9.86 \%$ & $50,000.00$ \\
\hline & & $\begin{array}{l}\text { Instrumentation and } \\
\text { controls }\end{array}$ & $9.47 \%$ & $48,000.00$ \\
\hline & & Electrical systems & $9.86 \%$ & $50,000.00$ \\
\hline & & Buildings & $7.89 \%$ & $40,000.00$ \\
\hline & & Yard improvements & $3.94 \%$ & $20,000.00$ \\
\hline & & Construction & $15.78 \%$ & $80,000.00$ \\
\hline & & \multicolumn{2}{|c|}{ TOTAL } & $507,000.00$ \\
\hline
\end{tabular}

${ }^{*}$ Refer the item code to (Figure S3).

The surplus treatment practice costs may reach $50 \%$ of the equipment cost, which is equivalent to U.S.D 84,500.00. Therefore, the TCI of the production unit could outstretch U.S.D 591,500.00. WCC is considered to be $6.5 \%$ of the FCE (U.S.D 38,447.50). As a result, permitting Equation (4), the TCI of U.S.D 629,947.50 could be premeditated. The TEA is considered one of the superlative methods to assess the efficacy of any eccentric scheme for PhACs productivity.

\subsection{Annual Operation Cost}

The annual operating cost (AOC) for the production, purification, and applications of PhACs consists of the cost of underdone materials (C-RM), production process waste (C-WG), utilities $\left(\mathrm{C}_{-\mathrm{U}}\right)$, and extra costs $\left(\mathrm{C}_{-\mathrm{E}}\right)$ such as extra maintenance or any other emergency things such as downing tools due to any technical defect in the equipment during the production of bioactive compounds as assessed on an anniversary basis in accordance with Equation (5).

$$
A O C=C_{R M}+C_{W G}+C_{U}+C_{E}
$$

The $C_{R M}$ calculates the portion of raw materials used as a production medium and the chemicals needed for the production and purification manufactured by a domestic supplier. The $C_{U}$ comprises electricity and water that are mandatory for the operation progression and predictable grounded on the price for each component in the native exchange. The $C_{W G}$ characterizes the ultimate biomass yield produced in the production process of the PhACs. The AOC is for the production, purification, and applications of pharmaceutical active compounds. The raw supplies cost $\left(C_{R M}\right)$ was probable at U.S.D 438,700.00/year, as described in Table 5. The estimated cost of the entire charge of utilities was U.S.D 100,000 /year, as conveyed in China. This approximation is on the contrary reported in Malaysia. The operating labor entails 10 hands with a mediocre salary of U.S.D 120,000 year. The preservation and insurance were projected as 2 and $1 \%$ of the FCE, respectively, as reported Gunukula et al. [35]. 
Table 5. Annual operation cost of the production of PhACs in submerged fermentation unit using Thornton's medium after optimization via RSM.

\begin{tabular}{|c|c|c|c|c|c|}
\hline & Component & Price (U.S.D) & Unit & Quantity & $\begin{array}{c}\text { Total Cost } \\
\text { (U.S.D) }\end{array}$ \\
\hline $\begin{array}{c}\text { Raw } \\
\text { material }\end{array}$ & $\mathrm{K}_{2} \mathrm{HPO}_{4}$ & 80 & $\mathrm{~kg}$ & $1000 \mathrm{~kg}$ & $80,000.00$ \\
\hline \multirow[t]{11}{*}{ (chemicals) } & $\mathrm{KNO}_{3}$ & 100 & $\mathrm{~kg}$ & $500 \mathrm{~kg}$ & $50,000.00$ \\
\hline & $\mathrm{MgSO}_{4} \cdot 2 \mathrm{H}_{2} \mathrm{O}$ & 300 & $\mathrm{~kg}$ & $200 \mathrm{~kg}$ & $60,000.00$ \\
\hline & $\mathrm{CaCl}_{2} \cdot \mathrm{H}_{2} \mathrm{O}$ & 100 & $\mathrm{~kg}$ & $100 \mathrm{~kg}$ & $10,000.00$ \\
\hline & $\mathrm{NaCl}$ & 100 & $\mathrm{~kg}$ & $100 \mathrm{~kg}$ & $10,000.00$ \\
\hline & $\mathrm{FeCl}_{3}$ & 350 & $\mathrm{~kg}$ & $10 \mathrm{~kg}$ & 3500 \\
\hline & Glucose & 415 & $\mathrm{~kg}$ & $1500 \mathrm{~kg}$ & $62,200.00$ \\
\hline & Asparagine & 1500 & $\mathrm{~kg}$ & $50 \mathrm{~kg}$ & $75,000.00$ \\
\hline & $\mathrm{HCl}$ & $100 / \mathrm{L}$ & $1 \mathrm{~L}$ & $100 \mathrm{~L}$ & $10,000.00$ \\
\hline & $\mathrm{NaOH}$ & $160 / \mathrm{L}$ & $1 \mathrm{~L}$ & $50 \mathrm{~L}$ & 8000 \\
\hline & \multicolumn{3}{|c|}{ Reagents required for the purification } & & $20,000.00$ \\
\hline & \multicolumn{3}{|c|}{ Reagents required for the application test } & & $50,000.00$ \\
\hline \multirow{2}{*}{ Utilities } & Electricity & 0.04 & $\mathrm{kWh}$ & $1,000,000$ & $40,000.00$ \\
\hline & Water & 0.01 & U.S.D $/ \mathrm{m}^{3}$ & $6,000,000$ & $60,000.00$ \\
\hline \multirow{4}{*}{ Other costs } & \multirow[t]{2}{*}{ Labor } & \multirow[t]{2}{*}{12000} & U.S.D/ & \multirow[t]{2}{*}{10} & \multirow[t]{2}{*}{$120,000.00$} \\
\hline & & & employee & & \\
\hline & Maintenance & 2 & $\%$ of FCE & & 5070 \\
\hline & Insurance & 1 & $\%$ of FCE & & $10,140.00$ \\
\hline & & Total & & & $673,910.00$ \\
\hline
\end{tabular}

\subsection{PhACs Profitability and Annual Revenue}

The present rate of seven PhACs that were produced and purified in the current work are cyclo-(tryptophanyl-prolyl) (U.S.D 40/100 mg), chloramphenicol (U.S.D 6/1000 mg), cyclo-(L-Val-L-Pro) (U.S.D 200/100 mg), cyclo-(L-Leu-L-Pro) (U.S.D 220/100 mg), cyclo-(LPhe-L-Pro) (U.S.D 240/100 mg), cyclo-(L-Val-L-Phe) (U.S.D 250/100 mg), N-(7-hydroxy-6methyl-octyl)-acetamide (U.S.D 200/100 mg).

The specific cost of these products $C_{Z}$ (kg/U.S.D) is the deliberated, which is dependent on the utility $\operatorname{cost} C_{U}$, annual costs of capital $C_{C}$, raw material $\operatorname{cost} C_{R M}$, extra $\operatorname{cost} C_{E}$, and the annual PhACs production, as presented by [36] (Equation (6)).

$$
C_{Z}=\left(C_{C}+C_{U}+C_{R M}+C_{E}\right) / E_{P}
$$

The techno-economic analysis of the PhACs productivity from SUK 25 has revealed that at the optimum productivity of PhACs with $0.1 \mathrm{~m}^{3}$ was $17.142 \mathrm{~g}$ of cyclo-(tryptophanylprolyl), $14.27 \mathrm{~g}$ of chloramphenicol, $5 \mathrm{~g}$ of cyclo-(L-Val-L-Pro), $3.57 \mathrm{~g}$ of cyclo-(L-Leu-L-Pro), $2.857 \mathrm{~g}$ of cyclo-(L-Phe-L-Pro), $2.857 \mathrm{~g}$ of cyclo-(L-Val-L-Phe), and $4.285 \mathrm{~g} \mathrm{~N}$-(7-hydroxy6 -methyl-octyl)-acetamide was generated. Thus, the 27.75 runs throughout the year in $\mathrm{SmF}$ with $100 \mathrm{~m}^{3}$ for each run, the total quantity generated consists of $475 \mathrm{~kg}$ of cyclo(tryptophanyl-prolyl), $396 \mathrm{~kg}$ of chloramphenicol, $138.75 \mathrm{~kg}$ of cyclo-(L-Val-L-Pro), $99.1 \mathrm{~kg}$ of cyclo-(L-Leu-L-Pro), $79.2 \mathrm{~kg}$ of cyclo-(L-Phe-L-Pro), $79.2 \mathrm{~kg}$ of cyclo-(L-Val-L-Phe), and $118.9 \mathrm{~kg} \mathrm{~N}$-(7-hydroxy-6-methyl-octyl)-acetamide.

The total income for manufacturing these quantities offers U.S.D 1,313,776.00. An approximation of the local tax in Malaysia is 15\% (U.S.D 197,066.40) and AOC with FCE (U.S.D 673,910.00). The annual turnover (after the tax) of PhACs was U.S.D 442,799.60/year, 
as shown in Table 5. The average precise cost of $100 \mathrm{mg}$ of PhACs was evaluated to be U.S.D 48.61 per $100 \mathrm{mg}$, which is low-priced compared with the market price of U.S.D $164.3 / 100 \mathrm{mg}$ for the average. In this investigation, the 10-year records of the internal rate of return (IRR), payback period (PBP), and net present value (NPV) were gleaned for the assessment of the economics of PhACs production. The IRR designated the competence of the investment was more than $45 \%$ in this investigation, as shown in (Figure 6), which specifies that green PhACs are economically practicable. In addition, the cost of waste production will be calculated when this techno-economic analysis is applied for a future study.

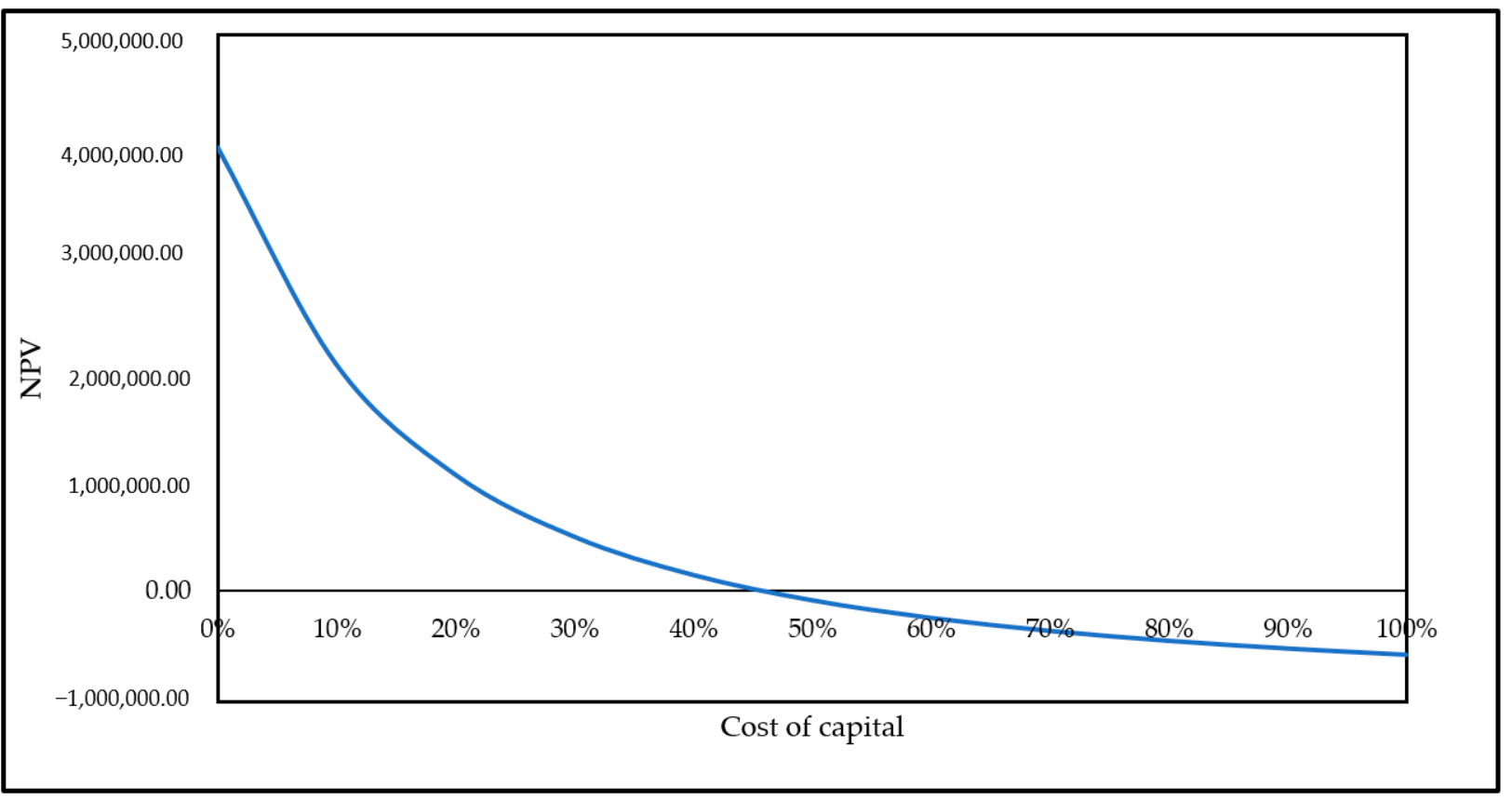

Figure 6. The IRR of the investment was more than $50 \%$ in this investigation.

\section{Discussion}

Different stages of optimization of fermentation have been analyzed using RSM. The key finding in this study was the statistical optimization of the significant media components that enhanced antibacterial activities against MRSA ATCC 43300 by using RSM. The model suggested that the glucose, asparagine, and mannitol affected the metabolite production from secondary metabolites produced by SUK 25, as reported with several earlier studies $[37,38]$. If the steepest descent experiments could be designed according to the findings of the dual-level factorial experiments, it will facilitate more insight into the optimal area of each significant factor. Moreover, the minor changes in media components, such as sources of carbon and nitrogen, or physical factors including agitation, aeration, temperature, fermentation incubation periods, and $\mathrm{pH}$ can considerably impact the quantity of the bacterial growth curve as in the level of $\log _{10}$ Colony-Forming Unit (C.F.U) $/ \mathrm{mL}$ [39].

In this study, we determined the value of the secondary metabolites and metabolic profiles of associated microorganisms, their activity based on the size of inhibition zone diameter, and the values of MIC. There is a need to develop viable options, which involve the application of statistical methods for optimization with the capacity to correct existing problems related to conventional optimization [23]. The fact that any component required for the growth of microorganisms is a potential substrate adds to the complexity in culture media optimization [40]. Therefore, the improvement of antibiotic yield will entail a design of the correct medium and determining the necessary conditions for cultivation [41]. In a previous study, the one-at-a-time strategy design was applied to assess the impact of 
carbon and nitrogen sources, $\mathrm{pH}$, and culture temperature on the production of bioactive compounds produced by SUK 25 strain as reported by Ahmad et al. [39]. On the contrary, the current study optimized the bioprocess using a combination of two methods. In the first method, the best nitrogen and carbon sources were selected for the growth of SUK 25 and precise measurement of the maximum weight of the crude extract, MIC, and maximum inhibition zone using the one-at-a-time strategy design. The findings from the present study are consistent with previous reports. The MIC values showed an improvement in the MIC values. Comparison with previous studies using Nocardia and Streptosporangium against S. aureus and MRSA showed that MIC against S. aureus were $30 \mu \mathrm{g}$ and MRSA $40 \mu \mathrm{g}$ [29]. The inhibition zone results are similar to a previous study carried by Mangzira Kemung et al. [42] where MUSC 125 towards MRSA ATCC 43300 showed the I.Z of $19 \pm 0 \mathrm{~mm}$, while the I.Z was $19.33 \pm 0.58 \mathrm{~mm}$ against MRSA ATCC 33591 .

The representations of the bonds of $\mathrm{N}-\mathrm{H}$ and $\mathrm{O}-\mathrm{H}$ stretching functional group represents carboxylic acids [43], and 2516, $2070 \mathrm{~cm}^{-1}$ bond $\mathrm{H}-\mathrm{C}=\mathrm{O}$ : $\mathrm{C}-\mathrm{H}$ stretch represents the aldehydes functional group and were also attributed to $C=C$ stretching of alkynes [44]. The peaks at $1558 \mathrm{~cm}-1$ show the bond $\mathrm{C}-\mathrm{C}$ stretch (in-ring) as the functional group for aromatics [45]. The peaks at $1449,1394 \mathrm{~cm}^{-1}$ represent $\mathrm{C}-\mathrm{H}$ bond, $\mathrm{C}-\mathrm{H}$ rock as the functional group for alkanes. The peaks at 1121,1092 , and $972 \mathrm{~cm}^{-1}$ are due to the presence of $\mathrm{C}-\mathrm{O}$ stretch (primary alcohol) and $=\mathrm{C}-\mathrm{H}$ bend alkenes, $\mathrm{O}-\mathrm{H}$ bending as carboxylic acids, and revealed the presence of $\mathrm{C}=\mathrm{O}$ stretching of acid anhydrides [27]. The band at $821 \mathrm{~cm}^{-1}$ shows aromatic compounds [16].

The GC-MS analysis revealed that among the 38 peaks, 21 compounds that demonstrate the presence of bioactive constituents have been previously reported for their antimicrobial [33], antioxidant [14], antifungal [15], anti-inflammatory activates [18], and neurotropic action $[18,19]$.

According to the gene ontology analyses of the biological function group, the most categories were under the adenosine monophosphate (AMP) salvage pathways, translation category, and metabolic process, followed by an oxidation-reduction process. Our findings are consistent with previous reports by Cui et al. [46]. The downregulated genes were under categories of the cell cycle, cell division, and cellular amino acid metabolic process, which corroborates the results from an earlier study by Guihua et al. [47]. The cellular function groups with the furthermost categories were under ribosome, cytoplasm, and ribonucleoprotein complex. These findings were published with the previous study that was conducted by Desaulniers et al. [48].

The most upregulated genes for the molecular function level were under categories of RNA binding, transferase activity, structural constituent of ribosome, oxidoreductase activity, and catalytic activity. These results are similar to the previous research conducted by Alam et al. [49].

The techno-economic analysis of the PhACs productivity from SUK 25 has revealed that the optimum productivity of PhACs with $0.1 \mathrm{~m}^{3}$ was cheaper than that in the market price. The average of the specific cost of $100 \mathrm{mg}$ of PhACs was evaluated to be U.S.D 48.61 per $100 \mathrm{mg}$, the market price was U.S.D $164.3 / 100 \mathrm{mg}$ for the average. These results are similar to the previous researches conducted by $[35,36]$.

In this study, the techno-economic viability and limitations that need more attention, while seeing the development-associated technologies with the major steps of the production of PhACs such as cultivation, harvesting, collection, logistics, pretreatment, fermentation, and separation will be improved during the production of the PhACs at the industrial level. In conclusion, the PhACs production activity against MRSA ATCC 43300 was improved by $42.9 \%$ of crude extract, from 16 to 4 and $8 \mu \mathrm{g} / \mathrm{mL}$ for MIC, while the I.Z increased by $5.8 \mathrm{~mm}$. The mechanism of CAP and DKP against MRSA acted by inhibiting protein synthesis, via preventing protein chain elongation by preventing the peptidyl transferase activity of the bacterial ribosome. The average specific cost of $100 \mathrm{mg}$ of PhACs was evaluated to be cheaper than that at market price. 
This study represents a preliminary study in the TEA, which is an initial exploration of the TEA technology by using SuperPro Designer software. The complete information will be in the next future study, which will calculate the amount of hot water, steam, heat, and waste production. In addition, it will calculate the flowrates of individual substances.

\section{Materials and Methods}

\subsection{Strain and Culture Condition}

The antibacterial compound producing strain, Streptomyces SUK 25, was previously isolated from the root of the Zingiber spectabile plant and extensively studied for their antibacterial secondary metabolites. The SUK 25 strain was maintained over the surface of ISP2 agar for 14 days before used [3].

\subsection{Basal Production Medium}

The SUK 25 was cultured on ISP2 agar media, followed by incubation at $28^{\circ} \mathrm{C}$ for 12 days. Then, a few blocks of ISP2 media containing pure and good growth of SUK 25 were transferred into $250 \mathrm{~mL}$ of modified Thornton's medium, which is composed of $(\mathrm{g} / \mathrm{L})$ $\mathrm{K}_{2} \mathrm{HPO}_{4} 1.0, \mathrm{KNO}_{3} 0.5, \mathrm{MgSO}_{4} \cdot 2 \mathrm{H}_{2} 0.2, \mathrm{CaCl}_{2} \cdot \mathrm{H}_{2} \mathrm{O} 0.1, \mathrm{NaCl} 0.1, \mathrm{FeCl}_{3} 0.01$, asparagine 0.5 , and glucose 1.5 and $\mathrm{pH} 7.4$ [50].

\subsection{RSM-Based Optimization of PHACs Production}

The experimental setup in the present research included optimizing the internal and external factors of the submerged fermentation $(\mathrm{SmF})$ with endophytic Streptomyces SUK 25, production, purification, and application of PhACs against MRSA ATCC 43300. The best operating parameters for PhACs production were assessed by response surface methodology (RSM) via central composite design (CCD), designed using the Design-Expert version 11 software. Factorial complete randomized design $(C R D)(7 \times 3 \times 3)$ in triplicate was employed to examine the independent variables affecting the PhACs production. Seven independent factors including incubation time $\left(x_{1}\right)$ (3-21 days), $\mathrm{pH}\left(x_{2}\right)(4-9),\left(x_{3}\right)$ temperature $\left(26-32{ }^{\circ} \mathrm{C}\right),\left(x_{4}\right)$ shaker rotation speed (120-180 rpm), $\left(x_{5}\right)$ glucose concentration $(1-3 \mathrm{~g} / \mathrm{L}),\left(x_{6}\right)$ mannitol concentration $(1-3 \mathrm{~g} / \mathrm{L}),\left(x_{7}\right)$ asparagine concentration $(0.5-2.5 \mathrm{~g} / \mathrm{L})$, and three points for each factor as well as three dependent variables were studied, and it included $y_{1}$ (crude extracts), $y_{2}$ minimum inhibitory concentration (MIC), and $y_{3}$ inhibition zone (I.Z), as described in Table 6. The selection of the range of each independent factor was as described by Kang et al. [13]. Three-stage testing, high (+), medium, and low (-), was conducted for each independent factor as presented in Table 6 .

Table 6. The min and max range for each independent factor used for pharmaceutically active compounds production from Streptomyces SUK 25.

\begin{tabular}{ccccc}
\hline $\begin{array}{c}\text { Medium } \\
\text { Components }\end{array}$ & Codes & $\begin{array}{c}\text { High Level } \\
(+)\end{array}$ & Medium Level & $\begin{array}{c}\text { Low Level } \\
(-)\end{array}$ \\
\hline $\begin{array}{c}\text { Incubation Time (day) } \\
\mathrm{pH}\end{array}$ & $\mathrm{x}_{1}$ & 21 & 12 & 0 \\
Temperature ${ }^{\circ} \mathrm{C}$ & $\mathrm{x}_{2}$ & 9 & 6 & 4 \\
Shaker rotation speed & $\mathrm{x}_{3}$ & 26 & 30 & 34 \\
$\quad \mathrm{rpm}$ & $\mathrm{x}_{4}$ & 180 & 160 & 120 \\
Glucose (g/L) & $\mathrm{x}_{5}$ & 3 & 2 & 1 \\
Mannitol (g/L) & $\mathrm{x}_{6}$ & 3 & 2 & 1 \\
Asparagine (g/L) & $\mathrm{x}_{7}$ & 2 & 1.0 & 0.5 \\
\hline
\end{tabular}

A total of thirty-seven experimental runs were carried out simultaneously to study the efficiency of the selected factors on the production. For the outcomes to be optimized in 
terms of the independent variables, the quadratic model was implemented as the following Equation (7) reported by Noman et al. [51].

$$
y=\beta 0+\sum_{i=1}^{k} \beta_{i} x_{i}+\sum_{i=1}^{k} \beta_{i i} x_{i}^{2}+\sum_{i=1}^{n} \sum_{i<j}^{n} \beta_{i j} x_{i} x_{j}
$$

where $y$ represents the expected responses for the production process; coefficients of the linear model are represented as $\beta_{0}, \beta i, \beta i i$, and $\beta i j$; coded independent factors $=x_{i}$; while $k$ represents the results of the responses.

The affiliation between the coded variable and experimental data is denoted as the following Equation (8):

$$
x_{i}=e_{i} \frac{[\mathrm{HL}+\mathrm{LL}] / 2}{[\mathrm{HL}-\mathrm{LL}] / 2}
$$

where $x_{i}$ denotes the coded variable, $e_{i}$ is the experiment results, LL and HL denote the lowest and the highest level of the independent factors.

\subsection{Submerged Fermentation and Extraction of Secondary Metabolites Methods}

The submerged fermentation $(\mathrm{SmF})$ process was carried out in a $250 \mathrm{~mL}$ Erlenmeyer flask containing Thornton's medium ( $\mathrm{g} / \mathrm{L})$, according to the composition presented by Alshaibani et al., 2016 [6]. The SmF pH medium was set to $\mathrm{pH} 7.4$ using $0.1 \mathrm{M}$ each of $\mathrm{HCl}$ and $\mathrm{NaOH}$. The flasks were plugged with foam caps and enclosed with aluminum foil, before being autoclaved at $121{ }^{\circ} \mathrm{C}$ for $15 \mathrm{~min}$. The autoclaved flasks were left to cool, then 100 microliter $(\mu \mathrm{L})$ of SUK 25 spore suspension were inoculated, as described by Thakur et al. [49]. The 37 runs of the fermentation process were carried out according to the RSM design, as presented in Table S1.

A Büchner funnel incorporated with Whatman ${ }^{\circledR}$ Grade 1 filter paper was used to filter the production medium by using the vacuum filtration. Thereafter, $100 \mathrm{~mL}$ of the supernatant was mixed with half volume $(50 \mathrm{~mL})$ of ethyl acetate (EtOAC) in 3 separated times, and homogenized at 125 rotation/minutes (rpm) for $1 \mathrm{~min}$. The separation and extraction of the PhACs from the supernatant was completed using $1 \mathrm{~L}$ separating funnels. The mixture of PhACs with EtOAC was separated by evaporation using a rotary evaporator RV 10 at $40^{\circ} \mathrm{C}$ for $30 \mathrm{~min}$ and vacuum at $240 \mathrm{mbar}$ [3].

All 37 runs were analyzed in triplicates, and the response was computed based on the mean antibacterial activity against MRSA ATCC 43300.

\subsection{Determination of Dependent Variables and Determination of Antibacterial Activity}

Three dependent variables were selected to be studied in this research according to the previous study reported by [25]. The first variable was $\left(y_{1}\right)$, which represents the weight of the crude extracts in milligram for each run. The weight of the crude extract obtained as ethanolic extract was determined using high-precision milligram balance (Intelligent-Lab ${ }^{\mathrm{TM}}$ Milligram Balance, PM series with $0.001 \mathrm{~g}$ accuracy); the means of the three runs were calculated. The second variable was $\left(y_{2}\right)$, which represents the MIC assay in $\mu \mathrm{g} / \mathrm{mL}$, and a 96-well plate was used for the MIC, which allowed a wider range of sample concentration and lower volume of samples to be tested. The third variable was $\left(y_{3}\right)$, which represents that the inhibition zone in mm was performed against MRSA ATCC 43300, according to the Clinical and Laboratory Standards Institute (CLSI) M 07- A10 (2016) [52].

\subsection{Purification of PhACs by Column Chromatography and Thin-Layer Chromatography}

To purify the PhACs, the production process was conducted using SmF in a $1 \mathrm{~L}$ Erlenmeyer flask containing $800 \mathrm{~mL}$ Thornton's medium based on the working parameters presented in Section 2.1. The procedure was performed at incubation time (day 12), $\mathrm{pH} 7$, temperature $28^{\circ} \mathrm{C}$, shaker rotation speed $(140 \mathrm{rpm})$, glucose $(2 \mathrm{~g} / \mathrm{L})$, mannitol $(1 \mathrm{~g} / \mathrm{L})$, asparagine $(2 \mathrm{~g} / \mathrm{L})$, as recommended by RSM. The crude containing the PhACs were separated, as described in Section 2.1. Thereafter, air-dried powder samples of ethyl acetate 
crude extracts were processed by weighing and mixing them with silica powder $(2 \mathrm{~g})$ and dried at room temperature. This mixture was subjected to separation through column chromatography (CC) size exclusion of $2 \times 40 \mathrm{~cm}$ containing $150 \mathrm{mg}$ of the Sephadex $\mathrm{LH}_{20}$. A linear gradient of $100 \%$ chloroform was used for the starting gradient elution, and the polarity of methanol was gradually increased (100:0, 95:5, 90:10, 85:15, 80:20, $70: 30,60: 40,50: 50$, and 0:100 v:v) to $100 \%$ in $30 \mathrm{~min}$. All the separates were dried upon column elution under lower pressure before using thin-layer chromatography (TLC) for another round of purification. Aluminum plates pre-coated with silica gel plates $60 \mathrm{~F}_{254}$ $(20 \times 20 \mathrm{~cm}, 0.25$ thickness, MERCK) were used. The TLC plates were developed using a solvent system and a mobile phase consisting of ethyl acetate, hexane, and methanol $(4: 4: 2$ volume/volume/volume $(v / v / v))$. To visualize the chromatograms, a short ultraviolet (UV) $(\lambda=254 \mathrm{~nm})$ and long-wavelength UV $(\lambda 365 \mathrm{~nm})$ were used for the absorbance and fluorescence, respectively. Then, the chromatograms were sprayed with $10 \% \mathrm{H}_{2} \mathrm{SO}_{4}$ in ethanol and heated at $100{ }^{\circ} \mathrm{C}$ for $10 \mathrm{~min}$. The compounds with comparable $\mathrm{R}_{\mathrm{f}}$ in TLC were mixed homogeneously, as reported by [53].

\subsection{Fourier Transform Infrared Spectroscopy Spectrometer}

The Fourier transform infrared spectroscopy (FT-IR) spectra was collected using a Perkin-Elmer-2000 spectrophotometer under a resolution of $4 \mathrm{~cm}^{-1}$ at 64 scans. A fixed weight $(2 \mathrm{mg}$ ) of the crude extract and pure compounds were deposited in the $\mathrm{KBr}$ disks to create a thin film. The records of all spectra were conducted from the range 4000 to $400 \mathrm{~cm}^{-1}$ and analyzed with the computer software program, Spectrum for Windows (Perkin-Elmer), as reported by [54]. For every sample, triplicate spectra were processed and analyzed.

\subsection{GC-MS Analysis of Volatile Components of Streptomyces SUK 25}

The Shimadzu GC-MS QF2010 EI/NCI system was used to analyze the incomplete purified active fractions from SUK 25. Other parts incorporated with the system include a film thickness of $0.25 \mu \mathrm{m}$, ZB-5MS capillary column I.D. $30 \mathrm{~m} \times 0.25 \mathrm{~mm}$, and $5 \%-$ phenyl-arylene stationary phase, as previously reported by Sharma et al. [55]. Thereafter, 1.0 microliter $(\mu \mathrm{L})$ of crude extract sample injected into the GC column for analysis, while maintaining the column and injector temperature at 70 and $200{ }^{\circ} \mathrm{C}$, respectively. A split mode ratio of 40 and a flow rate of $1.51 \mathrm{~mL} / \mathrm{min}$ were used. A similar flow rate (pressure of $105 \mathrm{kPa}$ ) was maintained for the carrier gas containing helium. The MS with ion $200{ }^{\circ} \mathrm{C}$, interface temp: $240{ }^{\circ} \mathrm{C}$, scan range: $40-1000 \mathrm{~m} / \mathrm{z}$, event time $0.5 \mathrm{~s}$, solvent cut time: $5 \mathrm{~min}$, MS start time: $5 \mathrm{~min}$, MS end time: $35 \mathrm{~min}$. In addition, the ionization voltage was EI $(-70 \mathrm{ev})$. A comparison between the mass spectra and the data from the National Institute of Standards and Technology, US (NIST05) was employed to identify the chemical compounds in the extract [56]. The software used in observing the chromatogram was again implemented for the final analysis, by determining and confirming the molecular weight, name, and peak area percentage of unknown compounds.

\subsection{Gene Ontology and Pathway Analysis}

The gene ontology, classified genes, gene products, and pathway analysis were conducted by using the web-based Kyoto Encyclopedia of Genes and Genomes (KEGG) databases and using the Database software for Annotation, Visualization, and Integrated Discovery (DAVID) (https:/ / david.ncifcrf.gov, Accessed on: 13 November 2020).

\subsection{Techno-Economic Analysis of the PhACs Productivity from SUK 25}

\subsubsection{Process Simulation}

The TEA was conducted for a facility that handles $1000 \mathrm{~m}^{3} /$ day of dry crude extract production in SmF process, isolated, and purified from SUK 25.

The facility was assumed operating $3300 \mathrm{~h}$ /year (interchangeable for 330 handling days). The TEA was developed based on experimental data from the previous studies, as 
indicated by [57]. The methods proposed have three stages intended as the production (A), purification (B), and applications (C) as illustrated in (Figure 7).
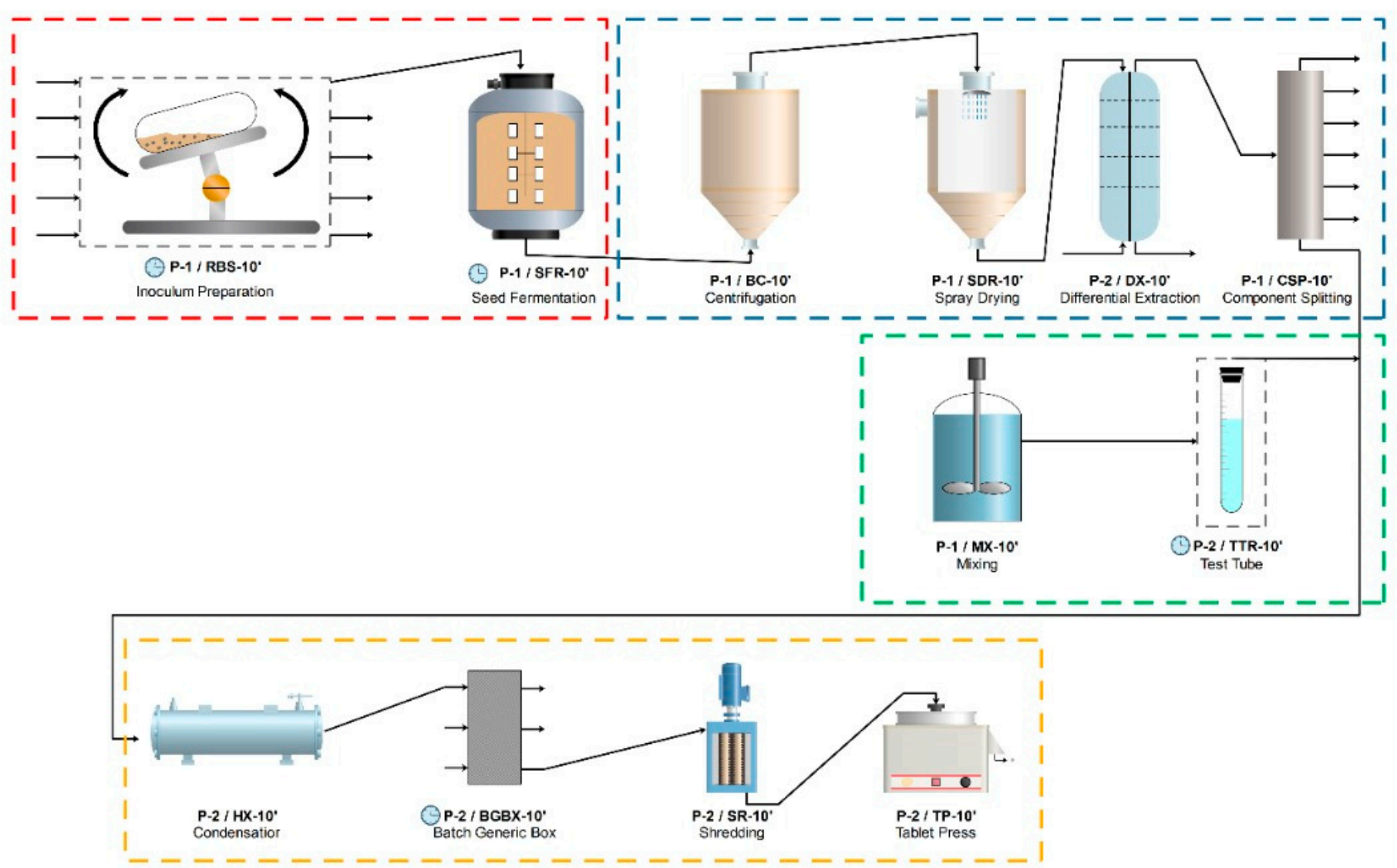

Figure 7. The proposed flowchart of PhACs production in SmF process.

\subsubsection{Production and Extraction of PhACs in SmF Media}

In phase A, the production of PhACs in SmF process was conducted. To improve the PhACs productivity, the SmF process was performed under the proper operating parameters as presented previously in the Section 4.4.

\subsubsection{Column Chromatography and Thin-Layer Chromatography}

In stage B, column chromatography and TLC were applied for the purification of PhACs, as presented in Section 4.6.

\subsubsection{Effectiveness of the PhACs and Determination of Antibacterial Activity}

In stage C, the effectiveness of the PhACs against the MRSA ATCC 43300 is carried out, as presented in Section 4.5.

\subsubsection{Economic Analysis}

The models built in the techno-economic analysis was applied by using the SuperPro Designer for the production of seven pure active compounds isolated and identified in our previous research from SUK 25 against MRSA ATCC 43300, as represents the first attempt of a TEA of production of PhACs from SUK 25. The proposed flowchart of PhACs was then established to estimate the capital and operating costs of each process. Table 4 details the fixed capital estimate (FCE) for production of PhACs by the SUK 25 using SmF and the other economic assumptions made in the study.

The cell culture bio-reactor, centrifuge, purification system, freeze drying, inoculum preparation, storage tank, microfiltration, aerobic bio-oxidation, dead end filtration, and 
biomass storage tank. In addition, the equipment installation, process piping, instrumentation and controls, electrical systems, buildings, yard improvements, and construction were considered in the analysis. This approach assumes that the technology is mature and that several of facilities employing the same process are established and are fully operational. Vendor quotes were used when the costs were not available for the row material [58]. The total direct costs were estimated as the sum of all the installed equipment costs, plus the costs for buildings, piping, and site development, as shown in Table 4.

\subsubsection{Annual Operation Cost}

The annual operating cost (AOC) for the production, purification, and applications of PhACs consists of the cost of underdone materials ( $\mathrm{C}-\mathrm{RM})$, production process waste (C-WG), utilities $\left(\mathrm{C}_{-\mathrm{U}}\right)$, and extra costs $\left(\mathrm{C}_{-\mathrm{E}}\right)$. The operating costs that include variable costs (feedstocks, utilities, etc.), fixed costs (salaries, maintenance, taxes, etc.), and general costs (e.g., marketing expenses) were estimated based on the principles, as reported by [58]. The C-U comprises electricity and water that are mandatory for the operation progression and predictable grounded on the price for each component in the native exchange. The C_WG characterizes the ultimate biomass yield produced in the production process of the PhACs. Techno-economic problems derive into demonstration when a procedure is scaledup or needs to be scaled-up to a marketable level. The main problem to be kept in mind is choosing the right optimized parameters, which are measured for cost economics. Reagents required for the purification and reagents required for the application test, electricity, and water as well as equipment used in the bioprocess are inclusive in the calculation. The sensitivity analysis was laboring to evaluate the influence that different conditions may have on the price of the purified PhACs.

\subsection{Statistical Analysis}

The linear effect of the independent factors and interactions between these factors were examined using analysis of variance (ANOVA), and $p$-values $\leq 0.05$ were considered significant. The efficiency of SmF for producing PhACs was investigated as a function for the quadratic model and coefficient adjusted $R\left(R^{2}\right.$ adj.). All experiments were conducted in triplicate. Three-dimensional (3D) graphical illustrations were used to depict the association between factors and the degradation process. To show the association between the experimental phases of each explanatory variable, 3D response surface plots were produced.

\section{Conclusions}

The most recognizable finding to appear from this study is that the PhACs' production activity against MRSA ATCC 43300 was improved by $42.9 \%$ of dry weight of the crude extract; MIC also enhanced from 16 to $8 \mu \mathrm{g} / \mathrm{mL}$, while the I.Z increased by $5.8 \mathrm{~mm}$. The GC-MS analysis revealed that 21 compounds that demonstrate the presence of bioactive constituents were identified. The mechanism of CAP and DKP against MRSA acted by inhibiting protein synthesis, via preventing protein chain elongation by preventing the peptidyl transferase activity of the bacterial ribosome. The average specific cost of $100 \mathrm{mg}$ of PhACs was evaluated to be cheaper than that at the market price.

Supplementary Materials: The following are available online, Figure S1: Three-dimensional response surface plot for interactions between $x_{1}$ (time) (day), $x_{2}(\mathrm{pH}), x_{3}$ (temperature) $\left({ }^{\circ} \mathrm{C}\right), x_{4}$ (speed) $(\mathrm{rpm}), x_{5}$ (glucose) $(\mathrm{g} / \mathrm{L}), x_{6}$ (mannitol) $(\mathrm{g} / \mathrm{L}), x_{7}$ (asparagine) $(\mathrm{g} / \mathrm{L})$ and their effects on $y_{2}((\mathrm{MIC})$ $(\mu \mathrm{g} / \mathrm{mL})$. Figure S2: Three-dimensional response surface plot for interactions between $x_{1}$ (time) (day), $x_{2}(\mathrm{pH}), x_{3}$ (temperature) $\left({ }^{\circ} \mathrm{C}\right), x_{4}$ (speed) $(\mathrm{rpm}), x_{5}$ (glucose) $(\mathrm{g} / \mathrm{L}), x_{6}$ (mannitol) $(\mathrm{g} / \mathrm{L}), x_{7}$ (asparagine) (g/L) and their effects on $y_{3}$ (I.Z) $\mathrm{mm}$. Table S1: The central composite design arrangement and responses for pharmaceutically active compounds production from Streptomyces SUK 25. Table S2; The regression coefficient and their significance of the quadratic model for pharmaceutically active compounds production from Streptomyces SUK 25. Table S3: Peaks absorbance values of FT-IR spectra of PHACs. 
Author Contributions: M.M.A.-S., N.M.Z., R.M.S.R.M. developed the theoretical formalism; A.A.-G., M.A.-S., H.A.E.E. performed the analytic calculations, and both authors A.A.-G. and M.M.A.-S. contributed to the final version of the manuscript. N.M.Z. and R.M.S.R.M. supervised the project. All authors have read and agreed to the published version of the manuscript.

Funding: FRGS (UKM-NN-03-FRGS0042-2009 and FRGS/1/2020/WAB02/UTHM/03/1.

Institutional Review Board Statement: Not applicable.

Informed Consent Statement: Not applicable.

Data Availability Statement: The data presented in this study are available in the article and in the Supplementary Data online at www.mdpi.com/xxx/s1 and https://drive.google.com/file/d/1DxbaSBpAia0q38SVc78LltY3WddPoNa/view?usp=sharing.

Acknowledgments: The authors appreciate the support and funding provided by the Ministry of Higher Education Malaysia (KPT) for the FRGS grant with reference code: FRGS UKM-NN-03FRGS0042-2009 and FRGS/1/2020/WAB02/UTHM/03/1-Photocatalysis of Trisiloxane and Pathogenic Bacteria in Greywater using Eco-Friendly Green Nanoparticles (ECO-GNPs) for Safe Disposal for this research project.

Conflicts of Interest: The authors declare no conflict of interest.

Sample Availability: Samples of the crude extract and secondary metabolites are available from the authors for a limited time.

\section{References}

1. Butini, M.E.; Abbandonato, G.; Di Rienzo, C.; Trampuz, A.; Di Luca, M. Isothermal Microcalorimetry Detects the Presence of Persister Cells in a Staphylococcus aureus Biofilm After Vancomycin Treatment. Front. Microbiol. 2019, 10, 332. [CrossRef]

2. Qi, D.; Zou, L.; Zhou, D.; Chen, Y.; Gao, Z.; Feng, R.; Zhang, M.; Li, K.; Xie, J.; Wang, W. Taxonomy and Broad-Spectrum Antifungal Activity of Streptomyces sp. SCA3-4 Isolated from Rhizosphere Soil of Opuntia stricta. Front. Microbiol. 2019, 10, 1390. [CrossRef]

3. Alshaibani, M.M.; Jalil, J.; Sidik, N.M.; Edrada-Ebel, R.; Zin, N.M. Isolation and characterization of cyclo-(tryptophanyl-prolyl) and chloramphenicol from Streptomyces sp. SUK 25 with antimethicillin-resistant Staphylococcus aureus activity. Drug Des. Devel. Ther. 2016, 10, 1817-1827.

4. AlShaibani, M.M.; Jalil, J.; Sidik, N.M.; Ahmad, S.J.; Kamal, N.; Edrada-Ebel, R.; Zin, N.M. Isolation, purification and characterization of five active diketopiperazine derivatives from endophytic Streptomyces SUK 25 with antimicrobial and cytotoxic activities. J. Microbiol. Biotechnol. 2017, 27, 1249-1256. [CrossRef]

5. Pathak, L.; Singh, V.; Niwas, R.; Osama, K.; Khan, S.; Haque, S.; Tripathi, C.K.M.; Mishra, B.N. Artificial Intelligence versus Statistical Modeling and Optimization of Cholesterol Oxidase Production by using Streptomyces Sp. PLoS ONE 2015, 10, e0137268. [CrossRef]

6. Konappa, N.; Udayashankar, A.C.; Krishnamurthy, S.; Pradeep, C.K.; Chowdappa, S.; Jogaiah, S. GC-MS analysis of phytoconstituents from Amomum nilgiricum and molecular docking interactions of bioactive serverogenin acetate with target proteins. Sci. Rep. 2020, 10, 1-23. [CrossRef]

7. Schulz-Bohm, K.; Martín-Sánchez, L.; Garbeva, P. Microbial Volatiles: Small Molecules with an Important Role in Intra- and Inter-Kingdom Interactions. Front. Microbiol. 2017, 8, 2484. [CrossRef]

8. Zin, N.M.; Al-Shaibani, M.M.; Jalil, J.; Sukri, A.; Al-Maleki, A.R.; Sidik, N.M. Profiling of gene expression in methicillin-resistant Staphylococcus aureus in response to cyclo-(l-Val-1-Pro) and chloramphenicol isolated from Streptomyces sp., SUK 25 reveals gene downregulation in multiple biological targets. Arch. Microbiol. 2020, 202, 1-10. [CrossRef]

9. Zhao, Y.; Wang, J.; Chen, J.; Zhang, X.; Guo, M.; Yu, G. A Literature Review of Gene Function Prediction by Modeling Gene Ontology. Front. Genet. 2020, 11, 400. [CrossRef]

10. Mikhelkis, L.; Govindarajan, V. Techno-Economic and Partial Environmental Analysis of Carbon Capture and Storage (CCS) and Carbon Capture, Utilization, and Storage (CCU/S): Case Study from Proposed Waste-Fed District-Heating Incinerator in Sweden. Sustainability 2020, 12, 5922. [CrossRef]

11. Kumar, V.; Al-Gheethi, A.; Asharuddin, S.M.; Othman, N. Potential of cassava peels as a sustainable coagulant aid for institutional wastewater treatment: Characterisation, optimisation and techno-economic analysis. Chem. Eng. J. 2020. [CrossRef]

12. Teymouri, A.; Adams, K.J.; Dong, T.; Kumar, S. Evaluation of lipid extractability after flash hydrolysis of algae. Fuel 2018, 224, 23-31. [CrossRef]

13. Kang, C.; Wen, T.-C.; Kang, J.-C.; Meng, Z.-B.; Li, G.-R.; Hyde, K.D. Optimization of Large-Scale Culture Conditions for the Production of Cordycepin with Cordyceps militarisby Liquid Static Culture. Sci. World J. 2014, 2014, 510627. [CrossRef] [PubMed]

14. Kang, E.B.; Mazrad, Z.A.I.; Robby, A.I.; In, I.; Park, S.Y. Alkaline phosphatase-responsive fluorescent polymer probe coated surface for colorimetric bacteria detection. Eur. Polym. J. 2018, 105, 217-225. [CrossRef] 
15. Jayakumar, V.; Sundar, A.R.; Viswanathan, R. Biocontrol of Colletotrichum falcatum with volatile metabolites produced by endophytic bacteria and profiling VOCs by headspace SPME coupled with GC-MS. Sugar Tech. 2021, 23, 94-107. [CrossRef]

16. Ahsan, T.; Chen, J.; Zhao, X.; Irfan, M.; Wu, Y. Extraction and identification of bioactive compounds (eicosane and dibutyl phthalate) produced by Streptomyces strain KX852460 for the biological control of Rhizoctonia solani AG-3 strain KX852461 to control target spot disease in tobacco leaf. AMB Express 2017, 7, 54. [CrossRef]

17. Padmavathi, A.R.; Abinaya, B.; Pandian, S.K. Phenol, 2,4-bis(1,1-dimethylethyl) of marine bacterial origin inhibits quorum sensing mediated biofilm formation in the uropathogen Serratia marcescens. Biofouling 2014, 30, 1111-1122. [CrossRef] [PubMed]

18. Ren, J.; Wang, J.; Karthikeyan, S.; Liu, H.; Cai, J. Natural anti-phytopathogenic fungi compound phenol, 2, 4-bis (1, 1-dimethylethyl) from Pseudomonas fluorescens TL-1. Indian J. Biochem. Biophys. 2019, 56, 162-168.

19. Bouaziz, F.; Koubaa, M.; Chaabene, M.; Barba, F.J; Ghorbel, R.E.; Chaabouni, S.E. High Throughput Screening for Bioactive Volatile Compounds and Polyphenols from Almond (Prunus amygdalus) Gum: Assessment of Their Antioxidant and Antibacterial Activities. J. Food Process. Preserv. 2016, 41, e12996. [CrossRef]

20. Barretto, D.; Vootla, S. GC-MS Analysis of Bioactive Compounds and Antimicrobial Activity of Cryptococcus rajasthanensis Ky627764 Isolated from Bombyx Mori Gut Microflora. Int. J. Adv. Res. 2018, 6, 525-538. [CrossRef]

21. Girija, S.; Duraipandiyan, V.; Kuppusamy, P.S.; Gajendran, H.; Rajagopal, R. Chromatographic Characterization and GC-MS Evaluation of the Bioactive Constituents with Antimicrobial Potential from the Pigmented Ink of Loligo duvauceli. Int. Sch. Res. Not. 2014, 2014, 820745. [CrossRef]

22. Gogoi, D.; Bora, G.; Borgohain, R.; Handique, J.G. Antioxidant Capacity and GC-MS Analysis of Hexane, Ethylacetate and Methanol Extracts of Ficus bhotanica-A Potential Folklore Medicinal Plant. Int. J. Pharmacogn. Phytochem. Res. 2018, 10, $201-212$.

23. Vanitha, V.; Vijayakumar, S.; Nilavukkarasi, M.; Punitha, V.; Vidhya, E.; Praseetha, P. Heneicosane-A novel microbicidal bioactive alkane identified from Plumbago zeylanica L. Ind. Crop. Prod. 2020, 154, 112748. [CrossRef]

24. Aparna, V.; Dileep, K.V.; Mandal, P.K.; Karthe, P.; Sadasivan, C.; Haridas, M. Anti-inflammatory property of n-hexadecanoic acid: Structural evidence and kinetic assessment. Chem. Biol. Drug Des. 2012, 80, 434-439. [CrossRef]

25. Manikandan, S.; Lakshmanan, G.M.A.; Ansarali, S. Identification of Bioactive Compounds from Selected Plectranthus Species by Gas Chromatography-Mass Spectroscopy and Fourier Transform Infra-Red Spectroscopy. J. Biol. Act. Prod. Nat. 2017, 7 , 438-451. [CrossRef]

26. Rahnama, K.; Jahanshahi, M.; Nasrollanejad, S.; Fatemi, M.H.; Tabarestani, M.S. Identification of Volatile Organic Compounds from Trichoderma virens (6011) by GC-MS and Separation of a Bioactive Compound via Nanotechnology. Int. J. Eng. 2016, 29, 1347-1353. [CrossRef]

27. Tonisi, S.; Okaiyeto, K.; Hoppe, H.; Mabinya, L.V.; Nwodo, U.U.; Okoh, A.I. Chemical constituents, antioxidant and cytotoxicity properties of Leonotisleonurus used in the folklore management of neurological disorders in the Eastern Cape, South Africa. 3 Biotech 2020, 10, 1-14. [CrossRef]

28. Karabay-Yavasoglu, N.U.; Sukatar, A.; Ozdemir, G.; Horzum, Z. Antimicrobial activity of volatile components and various extracts of the red AlgaJania rubens. Phytother. Res. 2007, 21, 153-156. [CrossRef]

29. Palanna, K.; Narendrappa, T.; Basavaraj, S.; Shreenivasa, K. Efficacy of Fungal and Bacterial Bio-control Agents on Ganoderma Spp. Causing Foot Rot of Arecanut. Int. J. Agric. Innov. Res. 2017, 6, 299-304.

30. Nguyen, N.H.; Nguyen, T.T.; Ma, P.C.; Ta, Q.T.H.; Duong, T.-H.; Vo, V.G. Potential Antimicrobial and Anticancer Activities of an Ethanol Extract from Bouea macrophylla. Molecules 2020, 25, 1996. [CrossRef]

31. Perveen, I.; Raza, M.A.; Iqbal, T.; Naz, I.; Sehar, S.; Ahmed, S. Isolation of anticancer and antimicrobial metabolites from Epicoccum nigrum; endophyte of Ferula sumbul. Microb. Pathog. 2017, 110, 214-224. [CrossRef]

32. Salem, M.Z.M.; Zayed, M.Z.; Ali, H.M.; El-Kareem, M.S.M.A. Chemical composition, antioxidant and antibacterial activities of extracts from Schinus molle wood branch growing in Egypt. J. Wood Sci. 2016, 62, 548-561. [CrossRef]

33. Yang, H.-T.; Chen, J.-W.; Rathod, J.; Jiang, Y.-Z.; Tsai, P.-J.; Hung, Y.-P.; Ko, W.-C.; Paredes-Sabja, D.; Huang, I.-H. Lauric Acid Is an Inhibitor of Clostridium difficile Growth in Vitro and Reduces Inflammation in a Mouse Infection Model. Front. Microbiol. 2018, 8, 2635. [CrossRef]

34. Herrera-Rodriguez, T.; Parejo-Palacio, V.; Gonzalez-Delgado, A.D. Technoeconomic sensibility analysis of industrial agar production from red Algae. Chem. Eng. Trans. 2018, 70, 2029-2034.

35. Gunukula, S.; Klein, S.J.; Pendse, H.P.; DeSisto, W.J.; Wheeler, M.C. Techno-economic analysis of thermal deoxygenation based biorefineries for the coproduction of fuels and chemicals. Appl. Energy 2018, 214, 16-23. [CrossRef]

36. Han, W.; Hu, Y.; Li, S.; Huang, J.; Nie, Q.; Zhao, H.; Tang, J. Simultaneous dark fermentative hydrogen and ethanol production from waste bread in a mixed packed tank reactor. J. Clean. Prod. 2017, 141, 608-611. [CrossRef]

37. Bhatia, S.K.; Lee, B.-R.; Sathiyanarayanan, G.; Song, H.-S.; Kim, J.; Jeon, J.-M.; Kim, J.-H.; Park, S.-H.; Yu, J.-H.; Park, K.; et al. Medium engineering for enhanced production of undecylprodigiosin antibiotic in Streptomyces coelicolor using oil palm biomass hydrolysate as a carbon source. Bioresour. Technol. 2016, 217, 141-149. [CrossRef]

38. Navarrete-Bolaños, J.L.; Téllez-Martínez, M.G.; Miranda-López, R.; Jiménez-Islas, H. An experimental strategy validated to design cost-effective culture media based on response surface methodology. Prep. Biochem. Biotechnol. 2017, 47, 578-588. [CrossRef]

39. Ahmad, S.J.; Suhaini, S.; Sidek, H.M.; Basri, D.F.; Zin, N.M. Anti-methicillin resistant Staphylococcus aureus activity and optimal culture condition of Streptomyces sp. SUK 25. Jundishapur J. Microbiol. 2015, 8, e16784. [CrossRef] 
40. Das, R.; Romi, W.; Das, R.; Sharma, H.K.; Thakur, D. Antimicrobial potentiality of actinobacteria isolated from two microbiologically unexplored forest ecosystems of Northeast India. BMC Microbiol. 2018, 18, 1-16. [CrossRef]

41. Yun, T.Y.; Feng, R.J.; Zhou, D.B.; Pan, Y.Y.; Chen, Y.F.; Wang, F.; Yin, L.Y.; Zhang, Y.D.; Xie, J.H. Optimization of fermentation conditions through response surface methodology for enhanced antibacterial metabolite production by Streptomyces sp. 1-14 from cassava rhizosphere. PLoS ONE 2018, 13, e0206497. [CrossRef]

42. Kemung, H.M.; Tan, L.T.-H.; Chan, K.-G.; Ser, H.-L.; Law, J.W.-F.; Lee, L.-H.; Goh, B.-H. Streptomyces sp. Strain MUSC 125 from Mangrove Soil in Malaysia with Anti-MRSA, Anti-Biofilm and Antioxidant Activities. Molecules 2020, $25,3545$. [CrossRef] [PubMed]

43. Song, H.; Liu, G.; Zhang, J.; Wu, J. Pyrolysis characteristics and kinetics of low rank coals by TG-FTIR method. Fuel Process. Technol. 2017, 156, 454-460. [CrossRef]

44. Lindenmaier, R.; Williams, S.D.; Sams, R.L.; Johnson, T.J. Quantitative Infrared Absorption Spectra and Vibrational Assignments of Crotonaldehyde and Methyl Vinyl Ketone Using Gas-Phase Mid-Infrared, Far-Infrared, and Liquid Raman Spectra: S-cis vs s-trans Composition Confirmed via Temperature Studies and ab Initio Methods. J. Phys. Chem. A 2017, 121, 1195-1212. [CrossRef]

45. Dong, C.-D.; Chen, C.-W.; Hung, C.-M. Synthesis of magnetic biochar from bamboo biomass to activate persulfate for the removal of polycyclic aromatic hydrocarbons in marine sediments. Bioresour. Technol. 2017, 245, 188-195. [CrossRef]

46. Cui, L.; Wang, X.; Huang, D.; Zhao, Y.; Feng, J.; Lu, Q.; Pu, Q.; Wang, Y.; Cheng, G.; Wu, M.; et al. CRISPR-cas3 of Salmonella Upregulates Bacterial Biofilm Formation and Virulence to Host Cells by Targeting Quorum-Sensing Systems. Pathogens 2020, 9 , 53. [CrossRef]

47. Guihua, Z.; Cao, S.; Zhang, G.; Xiao, Y.; Liu, S.; Shang, Y. Florfenicol-induced Mitochondrial Dysfunction Suppresses Cell Proliferation and Autophagy in Fibroblasts. Sci. Rep. 2017, 7, 1-13. [CrossRef]

48. Desaulniers, A.B.; Kishore, N.; Adames, K.; Nargang, F.E. Characterization of Single Gene Deletion Mutants Affecting Alternative Oxidase Production in Neurospora crassa: Role of the yvh1 Gene. Microorganisms 2020, 8, 1186. [CrossRef]

49. Alam, A.; Imam, N.; Ahmed, M.M.; Tazyeen, S.; Tamkeen, N.; Farooqui, A.; Malik, Z.; Ishrat, R. Identification and Classification of Differentially Expressed Genes and Network Meta-Analysis Reveals Potential Molecular Signatures Associated with Tuberculosis. Front. Genet. 2019, 10, 2029-2034. [CrossRef]

50. Thakur, D.; Bora, T.; Bordoloi, G.; Mazumdar, S. Influence of nutrition and culturing conditions for optimum growth and antimicrobial metabolite production by Streptomyces sp. 201. J. Med Mycol. 2009, 19, 161-167. [CrossRef]

51. Noman, E.; Al-Gheethi, A.; Talip, B.A.; Mohamed, R.; Kassim, A.H. Oxidative enzymes from newly local strain Aspergillus iizukae EAN605 using pumpkin peels as a production substrate: Optimized production, characterization, application and techno-economic analysis. J. Hazard. Mater. 2020, 386, 121954. [CrossRef]

52. Clinical and Laboratory Standards Institute (CLSI). Performance Standards for Antimicrobial Susceptibility Testing, 26th ed.; CLSI document M100-S26; Clinical and Laboratory Standards Institute: Wayne, PA, USA, 2016.

53. Gerlach, A.D.C.L.; Gadea, A.; da Silveira, R.M.B.; Clerc, P.; Lohézic-le Dévéhat, F. The use of anisaldehyde sulfuric acid as an alternative spray reagent in TLC analysis reveals three classes of compounds in the genus Usnea adans.(Parmeliaceae, li-chenized Ascomycota). Preprints 2018. [CrossRef]

54. She, W.; Ye, W.; Shi, Y.; Zhou, L.; Zhang, Z.; Chen, F.; Qian, P.-Y. A novel chresdihydrochalcone from Streptomyces chrestomyceticus exhibiting activity against Gram-positive bacteria. J. Antibiot. 2020, 73, 429-434. [CrossRef]

55. Sharma, P.; Kalita, M.C.; Thakur, D. Broad Spectrum Antimicrobial Activity of Forest-Derived Soil Actinomycete, Nocardia sp. PB-52. Front. Microbiol. 2016, 7, 347. [CrossRef]

56. Al-Dhabi, N.A.; Esmail, G.A.; Duraipandiyan, V.; Arasu, M.V.; Salem-Bekhit, M.M. Isolation, identification and screening of antimicrobial thermophilic Streptomyces sp. Al-Dhabi-1 isolated from Tharban hot spring, Saudi Arabia. Extremophiles 2015, 20, 79-90. [CrossRef]

57. Gopalakrishnan, Y.; Al-Gheethi, A.; Malek, M.A.; Azlan, M.M.; Al-Sahari, M.; Mohamed, R.R.; Alkhadher, S.; Noman, E. Removal of Basic Brown 16 from Aqueous Solution Using Durian Shell Adsorbent, Optimisation and Techno-Economic Analysis. Sustainability 2020, 12, 8928. [CrossRef]

58. Jones, S.B.; Zhu, Y.; Anderson, D.B.; Hallen, R.T.; Elliott, D.C.; Schmidt, A.J.; Drennan, C. Process Design and Economics for the Conversion of Algal Biomass to Hydrocarbons: Whole Algae Hydrothermal Liquefaction and Upgrading. (No. PNNL-23227); Pacific Northwest National Lab.(PNNL): Richland, WA, USA, 2014. 